Research, part of a Special Feature on Applying Landscape Science to Natural Resource Management

\title{
A Methodology to Map Ecosystem Functions to Support Ecosystem Services Assessments
}

\author{
Mik Petter ${ }^{1}$, Shannon Mooney ${ }^{1}, \underline{\text { Simone M. Maynard }}^{1,2}$, Andrew Davidson $^{1}$, Melanie Cox $^{3}$ and Ila Horosak $^{4}$
}

ABSTRACT. The project developed and trialed a method of mapping ecosystem functions in South East Queensland using biophysical data layers in preference to land use surrogates. Biophysical data and surrogates were identified for 19 ecosystem functions and maps were produced for each. Data layers for each ecosystem function were standardized for mapping purposes using existing expert advice or data quantiling. Two versions of the total ecosystem function overlap maps were also produced, showing areas of high ecosystem function that have the potential to contribute to high ecosystem service provision. This method was successfully used to replace land use surrogates in most cases, and produced maps that planners and decision makers considered credible. The mapping exercise allowed an ecosystem services framework (the SEQ Ecosystem Services Framework) to be embedded in a statutory planning document, used in a State of the Region Report and to influence planning decisions at a local government level.

Key Words: ecosystem functions; ecosystem services; GIS mapping; land use planning; South East Queensland

\section{INTRODUCTION}

Ecosystem services (ES) are the benefits people receive from ecosystems (Millennium Ecosystem Assessment 2005). According to Maynard et al. (2010:5), quantification and mapping of ecosystem services provides key information identifying: "(a) areas that provide a high level of service requiring protection or management to maintain service provision (b) areas that provide specific ecosystem functions or services and (c) changes in ecosystem service provision over time".

Spatial representation of the relative provision of ecosystem services across a landscape is critical for incorporating ecosystem services into processes for integrated urban and regional planning. However, mapping the location of ecosystem service derivation and provision can be constrained by the lack of data that describe landscapes in terms of services. ES are not commonly considered in land use planning because the tools and information for decision makers have not yet been available. This includes information on who the beneficiaries of ecosystem services are, along with their perceptions of the value of ecosystem services.

Ecosystem function maps were produced to provide spatial support for the SEQ Ecosystem Services Framework (henceforth, the Framework), an agreed framework developed by SEQ stakeholders to identify, measure, and value ecosystem services specifically for land use and natural resource management policy and planning (Maynard et al. 2010). Although a brief overview of the Framework are provided, the focus in this article is only on the production of the ecosystem function maps.

According to the Framework, those areas in SEQ showing a high amount of ecosystem function also have the potential to provide a high amount of ecosystem service(s). The key distinction between ecosystem functions and services is that functions are regarded as having both intrinsic and potential anthropocentric values, while services are defined only in terms of their benefits to people. For example, the ecosystem function of pollination is important for sustaining ecosystems and biodiversity for its own sake, while the service of pollination refers more specifically to the pollination of food or fuel crops of use to humans, or even indirectly for maintaining ecosystems and biodiversity to continue the supply of ecosystem services. The approach of mapping the ecosystem functions that underlie ecosystem services as a way forward to the eventual mapping of ecosystem services and their beneficiaries was adopted. Other researchers (Kremen and Ostfield 2005, Sanchirico and Mumby 2009) have highlighted the importance of understanding functional linkages between species and specific ecosystems and functional relationships between species for understanding ecosystem services.

Previous ecosystem service mapping approaches have used land use and land use zones as surrogates (Costanza et al. 1997, Costanza et al. 2006, Liu et al. 2010). This approach provides a rapid path to ecosystems service mapping but may not be sufficient in itself for detailed planning purposes. Land use describes what humans perceive as the land's utility whereas land cover describes the actual measured properties of the land surface (Witte et al. 2006, Carlson and Arthur 2000). Land use mapping is often done on a cadastral basis and can lack the sub-cadastral resolution of land cover. Land use mapping can also miss the topographic context of land use, which can impact on the provisioning of ecosystem function and services (Carlson and Arthur 2000). The SEQ Ecosystem Services Framework (Maynard et al. 2010) requires that the mapping 
be tied to enough specific information so that it could be used in both strategic and individual planning decisions. To try and address the issues by just using pure land use information, the ecosystem functions were mapped using a combination of land cover, lithographic attributes, topographic context, and in some instances, land use. This approach also allows for the exploration of different levels of functionality both between and within land uses.

This article reports on the identification and mapping of nineteen (19) ecosystem functions, which were recognized as underpinning the provision of ecosystem services in the South East Queensland (SEQ) region of Australia. It describes the method used in mapping individual functions and how these maps were overlaid to produce "Total Ecosystem Function" maps.

A list and the descriptions of ecosystem functions incorporated in the Framework is provided in Appendix 1. The Method section contains a description of the mapping process. The rationale for each of the data layers and the transformations required to develop the maps is provided in Appendix 2. The Results include a description of the individual function maps and the Total Ecosystem Function map, along with an example of Ecosystem Function 3: Disturbance Regulation. The Discussion section interprets the results and discusses data limitations. Applications of the mapping products and the implications of the methods used are described in the Conclusion.

\section{BACKGROUND}

\section{The SEQ region}

SEQ holds approximately $70 \%$ of the State of Queensland's population and is the fastest growing metropolitan area in Australia (Hinchcliffe 2009). The subtropical climate attracts on average 1057 new residents per week (Australian Bureau of Statistics 2010). The SEQ region is approximately $22,000 \mathrm{~km}^{2}$ of mountain ranges, hills, valleys, rivers, lakes, floodplains, coastal bays, and islands. SEQ is one of the most species-rich regions in Australia; nearly 5,000 native plant species and 900 species of native vertebrate have been recorded (Queensland Government 2003). Figure 1 shows the location of SEQ within Australia.

The SEQ coastal plain is relatively broad and flat, with undulating hills rising to mountains in the north (Glass House Mountains and Blackall Range), south (McPherson Ranges) and west (Great Dividing Range) of Brisbane. Eleven (11) major river systems and their tributaries traverse the coastal plain and form estuaries to Moreton Bay and the open coast. Moreton Bay is a mosaic of over 300 islands including three major sand islands and significant areas of coastal swamps, heathlands, mangroves, and sand dunes.
Fig. 1. The SEQ region and its location in Australia.
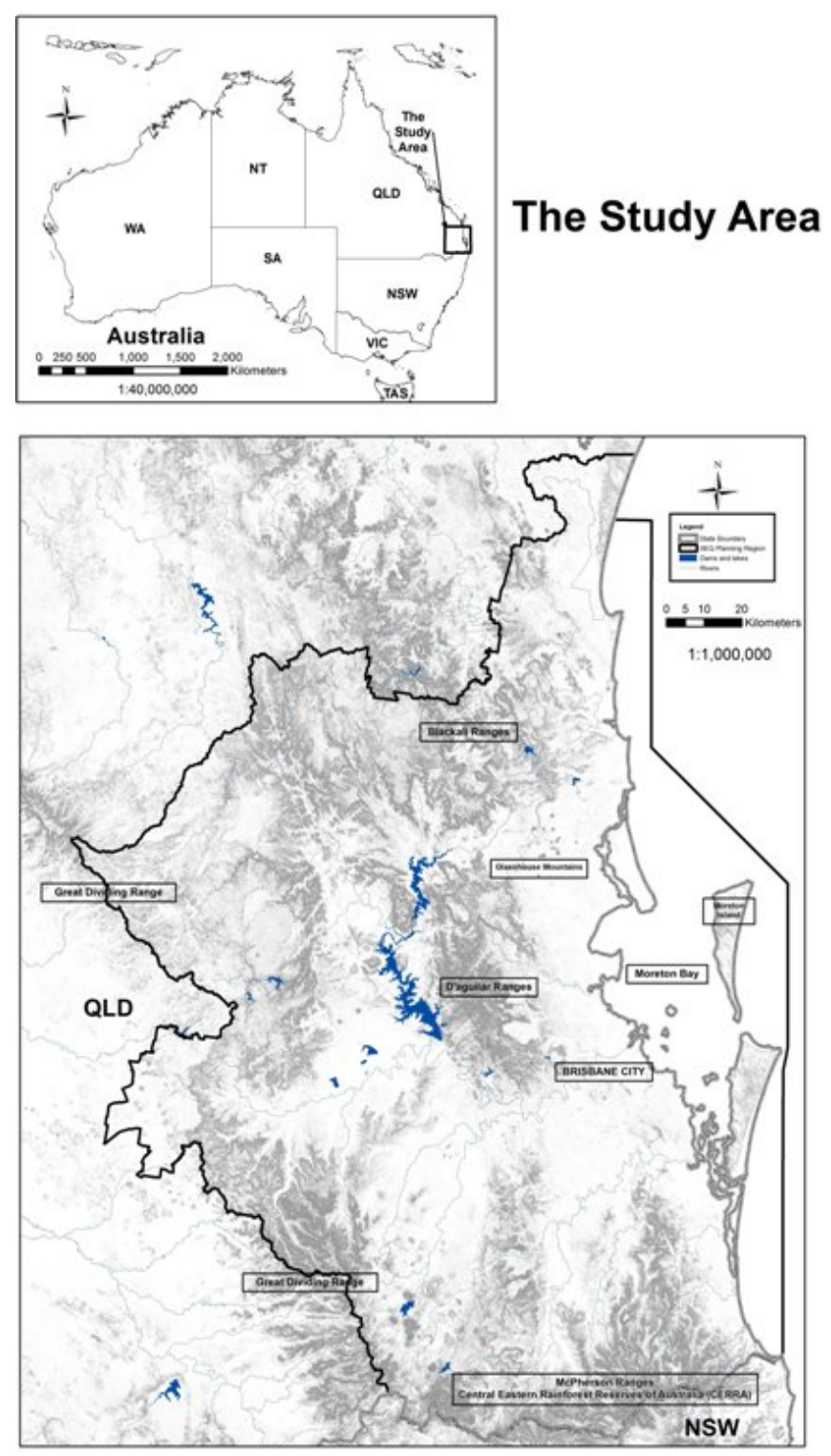

The southern portion of SEQ is dominated by volcanic highlands and includes parts of the Central Eastern Australia World Heritage area. The western area contains rich agricultural soils among the mountain ranges. These upland areas contain a diversity of plant and animal life that is often shared with grazing enterprises and rural residential land uses. The western catchments harvest water for the growing urban population settled mostly along the coast.

Such diverse landscapes attract pressure for multiple land use, which is often at odds with the sustainable management of natural resources in the region. The challenge for regional planning is to spatially describe these landscapes in a manner 
that allows planning to protect and enhance ecosystem function and the services they provide to the SEQ and wider community.

\section{The SEQ Ecosystem Services Framework}

Of critical importance to the development of the Framework was stakeholder consensus on the structure, terminology, and tools that would support the Framework. Maynard et al. (2012) describe the Framework as consisting of three main elements:

1. Lists and descriptions of four main components for assessment: Ecosystem Reporting Categories (groups of ecosystems), Ecosystem Functions, Ecosystem Services and Human Well-being;

2. A semi-quantitative description of the relationships between these in the form of scores and matrices; and

3. A series of maps identifying spatially where ecosystem services are being derived from in SEQ (i.e., maps of Ecosystem Reporting Categories and Ecosystem Functions).

The project to develop the Framework has relied heavily on a participatory process with inputs from its Steering Group, Working Group, Expert Panels, and Community Workshops. By creating forums for negotiation and information sharing, this approach also increased ownership, empowered stakeholders, and helped bridge different scales of information and forms of knowledge across sectors and disciplines (Millennium Ecosystem Assessment 2005, Cowling et al. 2008, Maynard et al. 2010, Maynard et al. 2012).

\section{MAPPING METHOD}

The maps described were prepared using an ESRI ArcGIS platform. The first phase of mapping used the descriptions for each of the ecosystem functions to produce one map for each of the 19 functions incorporated into the Framework. For the purposes of the Framework, ecosystem functions were defined as "the biological, geochemical and physical processes and components that take place or occur within an ecosystem" (Maynard et al. 2010:6).

The second phase of mapping overlaid each of the 19 individual function maps to produce a "Total Ecosystem Function" map. Two Total Ecosystem Function maps have been produced: one based on presence/absence and another on quartile standardization. As the final products (19 individual function and 2 Total Ecosystem Function maps) are a combination of data sources and corresponding map layers, consideration needed to be given to the parent scale, year of creation, accuracy of data, data models, and the minimum mapping unit for each input layer (Millennium Ecosystem Assessment 2005, Troy and Wilson 2006, Maynard et al. 2010).
Mapping was conducted in parallel with the review of definitions of ecosystem functions for the Framework, which necessitated ongoing refinement of appropriate data sets and proposed surrogate layers. Interim map products were subject to review through meetings and Think Tanks by relevant academic and technical experts as well as political and community stakeholders. The results presented are the current version (Version 4) and are subject to ongoing refinement and review as new information and data sets become available.

\section{Lists and descriptions of ecosystem functions}

The list of 19 ecosystem functions incorporated into the Framework was adapted from de Groot et al. (2002) during the Expert Panels. The list of ecosystem functions can be considered as broad groupings of ecosystem functions. For example, the function of gas regulation includes the regulation of many gases such as carbon, oxygen or nitrogen regardless of the type of process that transforms this species into its gaseous state. The number of ecosystem functions incorporated in the Framework is a subjective and arbitrary number dependent on the chosen scale or method of delineation. It was considered that the 19 functions defined were comprehensive and most important to the provisioning of ecosystem services in SEQ and a manageable number to assess within the Framework. The list of ecosystem functions and their descriptions is provided in Appendix 1, Table A1.1.

\section{Identification and interpretation of data sets}

To map individual ecosystem functions all available geographic information system (GIS) data sets were identified and collected and combined, to represent the 19 different biological, geochemical, and physical processes and components occurring in ecosystems that the Expert Panels had described. A request was made to partners and stakeholders for biophysical data sets of the SEQ landscape, different ecosystem types and land use maps that covered the full extent of the region. Analysis and blending of these multiple data sets was carried out to produce a probable spatial presentation of where in the landscape each particular ecosystem function is occurring.

While most of the data sets used were already developed, a number of ecosystem functions required the development of new data layers; these were developed in-house by the coordinating organization, SEQ Catchments). Seventeen (17) new layers were derived from existing data sets. Appendix 2, Table A2.1 lists the data sets applied to develop the 19 ecosystem function maps, the data source or reference, the rationale for each data set in terms of the function to which it was applied, and comments on the use of the data set or future recommendations for inclusion.

\section{Standardization of data sets}

To develop the individual function maps, each of the data sets was standardized to produce a common currency to facilitate the overlaying process within the GIS environment. The aim 
of this standardization process was to reduce each data set to a "presence" or "absence" ( 0 or 1$)$ and to ensure all data sets were at a consistent scale ( $25 \mathrm{~m} \times 25 \mathrm{~m}$ grid). Two methods of standardization were applied:

- Method A: For some data sets expert advice was provided with the Metadata and supporting documents. Using this advice, each data set was reduced to a presence or absence (0 or 1). For example, the Core Habitat data set from the Biodiversity Planning Assessment provided data as low, medium, high, and very high, which was reclassified as $1,2,3$, and 4 respectively. These were further reclassified to a standardized score of 0 (absent) for scores 1 and 2 and a standardized score of 1 (present) for scores 3 and 4 (i.e., only the 2 highest scores were retained).

- Method B: Where there was no inherent expert advice with the original data set for a presence or absence, quartile splits were used for numerical data. After arranging the data in ascending order a quartile split distributes the data into 4 equal parts (Serfling 1980). This would produce a range of scores from 1 through to 4. Scores of 1 and 2 were reclassified as absent and 3 and 4 as present, the same as in Method A.

\section{Map production}

The 19 ecosystem function maps were produced by overlaying the selected suite of standardized data sets to produce extent maps for each ecosystem function. While each data layer was not weighted in the individual ecosystem function overlay process, it was subjected to a prioritization process during standardization. Appendix 2, Table A2.1 is the resultant master list including a description of the contribution of each data set to a component of ecosystem function with relevant references.

While experts or resource managers may find utility in the individual ecosystem function maps, decisions makers at the regional level were looking for a product that summarized the level of ecosystem function provided. Those of the planning profession took the view that while we as yet could not map specific ecosystem services, we could protect those services in a planning sense by protecting areas that supplied a range of the necessary ecosystem function(s). This point of view led to the trialing of two styles of ecosystem function overlay maps (Total Ecosystem Function maps).

The first Total Ecosystem Function map (titled: Presence/ Absence) was developed by further reducing the information in each individual function map (e.g., Ecosystem Function 3: Disturbance Regulation) to a presence or absence and then overlaying all 19 function maps. For example, in the Disturbance Regulation map, if a cell was highlighted as performing that function it became present (values $=1$ ). If no data were identified to support that the function was performing in that area (cell) it became absent (0). Individual ecosystem function maps were then overlaid. The resulting Total Ecosystem Function map had a data range of 0 - 19.

The second Total Ecosystem Function map (titled: Quartile) was produced by quartiling each of the 19 individual function maps as described in the Total Ecosystem Function Maps section, Method B; maintaining all values 1 - 4 and then overlaying them. For example, each function map had a highest score of 4 and when combined (overlaid), cells in the resulting Total Ecosystem Function map had a potential data range of $0-76$.

\section{Peer review and version analysis}

Each stage in the development of the Framework is an iterative process of data collection, analysis, and review (Maynard et al. 2010). The first stage of peer review, including the mapping products, involved the presentation of the maps and underpinning data sets to the Steering Group containing representatives from State and Local Governments, nongovernment organizations, and leading academics. Once suggestions were accounted for through any required modifications, the maps and underpinning data sets were presented to an open forum of interested persons and organizations (the Working Group). Forums have seen representation from federal, state and local governments, agricultural organizations, business, industry, and nongovernment organizations.

\section{RESULTS}

\section{Individual ecosystem function maps}

In all, 19 ecosystem function maps were produced as well as two versions of Total Ecosystem Function maps. All 19 ecosystem function maps are contained in Appendix 3 presented as Figure A3.1 to A3.19. A brief interpretation of one of the 19 individual ecosystem function maps, namely, Function 3 (Disturbance Regulation) will now be presented The map itself is presented as Figure A3.3 in Appendix 3.

\section{Disturbance Regulation}

The description of this function as developed through the Expert Panels includes: the capacity of the soil, regolith, and vegetation to buffer the effects of wind, water, and waves through water and energy storage capacity and surface resistance. The soil profile stores water and reduces runoff. Vegetation enhances infiltration and provides surface resistance. Degraded soils and landscapes have a reduced capacity. Soil properties (e.g., depth, surface texture) and vegetation structure are important.

These are the areas of landscape that minimize flash floods, storm surges, landslips, excessive runoff, and a whole range of other processes that regulate the peaks and troughs in Australia's highly variable weather and rainfall (White and Karssies 1999). Fifteen (15) data sets or pathways to performing this function were applied to develop this map. 
Table 1. The data sets and frequency of use in the 19 individual ecosystem function maps (references to data custodians can be found in Table 2, Appendix 2).

\begin{tabular}{|c|c|}
\hline Data Sets Applied & \# of EFs applied to \\
\hline Good Grass Cover $^{\dagger}$ & 11 \\
\hline Woody Vegetation & 10 \\
\hline Wetlands & 9 \\
\hline Mangroves, Samphire and Salt Marsh; Floodplains and Coastal Deposits ${ }^{\dagger}$; Woody Vegetation on Streams ${ }^{\dagger}$; Sea Surface ${ }^{\dagger}$; Tidal Zone ${ }^{\dagger}$ & 7 \\
\hline $\begin{array}{l}\text { SEQ Biodiversity Planning Assessment V3.4; Good Agricultural Land (Classes A and B); SEQ Water Bodies; SEQ Streams; } \\
\text { Vegetation Corridors }\end{array}$ & 6 \\
\hline Seagrass; Euphotic Zone ${ }^{\dagger}$; Sand and Mudbanks ${ }^{\dagger} ;$ Vegetation Tracts ${ }^{\dagger}$ & 5 \\
\hline Fish Habitat Areas; Reefs; Rocky Reefs; Special Biodiversity Values; Woody Vegetation on Slopes ${ }^{\dagger}$; Good Streams ${ }^{\dagger}$ & 4 \\
\hline $\begin{array}{l}\text { Low Total Nitrogen; Low Total Phosphorus; Low Total Suspended Solids; Priority Taxa Nonremnant }{ }^{\dagger} \text {; High Rainfall }{ }^{\dagger} \text {; Reservoirs; } \\
\text { Threatened Species Habitat; Islands; Island Streams; Wet Forests; Regional Ecosystem Variety }{ }^{\dagger}\end{array}$ & 3 \\
\hline $\begin{array}{l}\text { High Ecosystem Values Aquatic; Core Habitat; FLAG Lowup; Managed Forests; Marine Park Conservation Zone; Marine Park } \\
\text { Habitat Zone; Sand and Gravel above } 5 \mathrm{~m}^{\dagger} \text {; Deeps and Drops }{ }^{\dagger} \text {; Heathlands; Midlands }{ }^{\dagger} \text {; Mountains }{ }^{\dagger}\end{array}$ & 2 \\
\hline $\begin{array}{l}\text { Broad Agriculture; Grey Nurse Habitat; Grazing; Density of Headwater Streams }{ }^{\dagger} \text {; Intensive Agriculture; Land less than } 5 \mathrm{~m}^{\dagger} \text {; Coastal } \\
\text { Dunes }{ }^{\dagger} \text {; Plantations; High Total Nitrogen; High Total Phosphorus; High Total Suspended Solids; Woody Vegetation less than } 5 \mathrm{~m}^{\dagger} \text {; } \\
\text { Wader Habitat and Roosts; Geo Diversity }{ }^{\dagger} \text {; Scenic Preference; Shelter }\end{array}$ & 1 \\
\hline
\end{tabular}

Seven (7) were directly related to vegetation, for example: vegetation on slopes, vegetation on streams, and areas with good groundcover. Other layers included water bodies for the capacity to hold and store water in times of high rainfall, coastal and dune systems for providing protection from coastal erosion during increased wind, waves, and storm surges.

Areas in dark blue on the Disturbance Regulation map show areas of highest data overlap with the coastal areas including the islands highlighted the most. Other areas also with high overlap include the higher elevated and high rainfall areas in the south and the north that still retain larger amounts of remnant vegetation, also, riparian areas and the floodplains at the bottom of these elevated areas. Areas with the least amount of data overlay were those containing agriculture, built infrastructure/settled areas, and some grasslands in the west of the region. Through the Expert Panel process, areas performing the function Disturbance Regulation are most important for providing the ecosystem services of: maintaining water quality, the area and extent of arable land, and buffering against extreme events.

\section{Data sets}

To develop the 19 ecosystem function maps, 59 unique data sets were identified that together and in different combinations would provide a representation of where individual ecosystem functions (important for maintaining ecosystems, biodiversity, and provision of ecosystem services) were taking place in the landscape. Some data sets were used to map more than one ecosystem function, but each data set was only applied once within each function even if it was considered that the data set was an appropriate surrogate for more than one pathway. The data sets applied, and the number of ecosystem function maps they were applied to, are presented in Table 1.
From inspection of Table 1 the data sets Good Grass cover, detected Woody Vegetation cover, and Wetlands were applied most in the development of the ecosystem function maps, and they were applied to 11,10 and 9 ecosystem functions respectively. There were 17 data sets used in five or more ecosystem functions. There were a further 26 data sets used for between two and four ecosystem functions. There were 16 data layers that were used for only one ecosystem function. Data sets developed specifically for the purposes of mapping ecosystem functions, i.e., the 23 derived layers as described in Appendix 2, Table A2.1, were applied in up to 11 functions and five derived layers were in seven or more functions. Six (6) of the derived layers were only used for one function.

Table 2 lists the number of data sets applied to develop each ecosystem function map and the maximum number of data overlays occurring in any given area. It also lists the percentage of area on the map where there were no data to support that the ecosystem function under investigation was being performed here. Percentages are also provided on the amount of area covered by just one data set or multiple data sets. The final column shows the percentage of actual data coverage for each function that contained greater than one data layer.

The highest number of data sets was required to map Supporting Habitats (29) and the lowest number was required to map Barrier Effect of Vegetation (one), Shade and Shelter closely followed with two data sets. On average 10 data sets were required to map each individual function, but overall the number of data sets required to map each function was highly variable. For each ecosystem function, over $50 \%$ of the data sets overlap at some place on the resulting map. 
Table 2. Summary of extent and data overlap for each ecosystem function map.

\begin{tabular}{|c|c|c|c|c|c|c|}
\hline Ecosystem Function & $\begin{array}{c}\text { \# of data sets } \\
\text { applied }\end{array}$ & $\begin{array}{l}\text { max \# of data } \\
\text { set overlap }\end{array}$ & $\begin{array}{c}\% \text { of SEQ area } \\
\text { no data/ no } \\
\text { function }\end{array}$ & $\begin{array}{c}\% \text { of SEQ } \\
\text { area = } 1 \text { data } \\
\text { set }\end{array}$ & $\begin{array}{c}\% \text { of SEQ } \\
\text { area }>1 \text { data } \\
\text { set } \\
\end{array}$ & $\begin{array}{c}\% \text { of data } \\
\text { coverage }>1 \\
\text { layer } \\
\end{array}$ \\
\hline EF 01 Gas Regulation & 10 & 8 & 13.73 & 49.12 & 37.15 & 43.06 \\
\hline EF 02 Climate Regulation & 7 & 5 & 3.04 & 56.63 & 40.33 & 41.60 \\
\hline EF 03 Disturbance Regulation & 15 & 9 & 39.17 & 24.31 & 36.52 & 60.03 \\
\hline EF 04 Water Regulation & 8 & 8 & 45.50 & 21.81 & 32.68 & 59.97 \\
\hline EF 05 Soil Retention & 4 & 4 & 51.00 & 27.29 & 21.71 & 44.31 \\
\hline EF 06 Nutrient Regulation & 14 & 11 & 26.88 & 26.88 & 49.02 & 64.58 \\
\hline EF 07 Waste Treatment & 13 & 10 & 25.98 & 34.54 & 39.48 & 53.34 \\
\hline EF 08 Pollination & 7 & 6 & 65.13 & 16.48 & 18.39 & 52.74 \\
\hline EF 09 Biological Control & 5 & 4 & 65.29 & 16.49 & 18.22 & 52.49 \\
\hline EF 10 Barrier Effect of Vegetation & 1 & 1 & 68.00 & 32.00 & 0.00 & 0.00 \\
\hline EF 11 Supporting Habitats & 29 & 16 & 32.28 & 27.15 & 40.57 & 59.91 \\
\hline EF 12 Soil Formation & 7 & 6 & 61.18 & 20.15 & 18.68 & 48.11 \\
\hline EF 13 Food & 16 & 8 & 54.83 & 32.09 & 13.08 & 28.95 \\
\hline EF 14 Raw Materials & 6 & 5 & 63.97 & 11.65 & 24.38 & 67.67 \\
\hline EF 15 Water Supply & 11 & 10 & 46.87 & 17.16 & 35.97 & 67.69 \\
\hline EF 16 Genetic Resources & 15 & 9 & 55.82 & 17.07 & 27.11 & 61.36 \\
\hline EF 17 Shade \& Shelter & 2 & 2 & 64.73 & 33.55 & 1.72 & 4.87 \\
\hline EF 18 Pharmacological Resources & 9 & 6 & 71.97 & 21.18 & 6.85 & 24.43 \\
\hline EF 19 Landscape Opportunity & 25 & 12 & 2.01 & 32.97 & 65.02 & 66.36 \\
\hline
\end{tabular}

The ecosystem functions Landscape Opportunity, Climate Regulation, Gas Regulation, Nutrient Regulation, Waste Treatment, Supporting Habitats, and Disturbance Regulation occurred over a broad area with $60 \%$ coverage of the SEQ region. The ecosystem functions with the narrowest areas were Pharmacological Resources, Barrier Effect of Vegetation, Biological Control, Pollination, Shade and Shelter, Raw Materials, and Soil Formation, which all had less than $40 \%$ coverage. If areas of no data/no function are excluded for eleven of the ecosystem functions over $50 \%$ of their map area is made up of one or more layers. For two of the ecosystem functions "Shade and Shelter" and "Barrier effect of vegetation" this figure is less than $10 \%$. For the remaining three ecosystem functions it is above $40 \%$. Where there were data, the coincidence of data overlap was strong, revealing the many pathways for those landscapes to provide for ecosystem services.

\section{Total Ecosystem Function Maps}

The two Total Ecosystem Function maps are presented as Figures A4.1 and A5.1 in Appendices 4 and 5 respectively, and will now be described in more detail.

\section{Total Ecosystem Function Map: Presence/Absence}

The Total Ecosystem Function Map is the composite of all 19 function layers and their interaction within the region. The areas of high function overlap represented by dark blue on the map included largely natural areas, high ecological health streams in headwater areas, elevated landscapes, freshwater wetlands and coastal wetlands, and marine ecosystems, such as seagrass meadows and shallows. It was noted that high ecosystem functions were scattered across the landscape even within the urban and built environment. Areas of lower ecosystem functions occurred in some cropping areas, urban and rural residential areas, and the marine environment. In some cases such as the marine environment, data gaps were the cause of low scoring.

Table 3 shows across the region peaks in ecosystem function overlap occurred at two, four, seven, 14 and 18 overlying functions with the highest peak at seven function overlaps. Areas that had just one mapped function occupied $17.32 \%$ of the area and only $0.42 \%$ had no mapped function. Only $2.92 \%$ of the area had the highest possible function overlap (i.e., 19 functions). This method of map development compensated for areas where there were little data available.

\section{Total Ecosystem Function Map: Quartile}

The quartiling approach weighted data overlap within each ecosystem function with a score of one to four, with a four having highest overlap. Combining the 19 quartiled ecosystem function layers, the highest total achievable is 76 with 68 being observed. High function overlap is represented by dark blue on the map and includes islands, elevated areas and upper catchment reaches, healthy streams, and largely natural areas. Areas of high and low function overlap were similar to the Presence/Absence method, however, more defined given the larger data range. For example, rather than the whole of Moreton Island being high as in the Presence/Absence method, the eastern fore dunes and western ecosystems are providing more functions as well as the southern tip that mostly supports wetland communities.

Some data layers were used in a large number of ecosystem function maps and so contributed more to the total ecosystem 
function map than others. In particular, woody vegetation, remnant vegetation, good grass cover, wetlands, and deeper soils appeared in a number of layers as shown in the results.

Table 3. Number of ecosystem function overlaps by the $\%$ of SEQ area.

\begin{tabular}{cc}
\hline \hline $\begin{array}{c}\text { Number of overlapping ecosystem } \\
\text { functions }\end{array}$ & $\%$ of SEQ area with overlap \\
\hline 0 & 0.42 \\
1 & 17.32 \\
2 & 9.75 \\
3 & 0.92 \\
4 & 8.85 \\
5 & 1.90 \\
6 & 2.83 \\
7 & 12.93 \\
8 & 2.05 \\
9 & 1.74 \\
10 & 1.67 \\
11 & 2.30 \\
12 & 2.54 \\
13 & 3.15 \\
14 & 5.90 \\
15 & 2.63 \\
16 & 3.62 \\
17 & 5.86 \\
18 & 10.70 \\
19 & 2.92 \\
\hline
\end{tabular}

Table 4. Number of data sets overlapping by the \% of SEQ area.

\begin{tabular}{cc}
\hline \hline Number of overlapping data sets & \% of SEQ area with overlap \\
\hline 0 & 0.421 \\
$1-10$ & 51.667 \\
$11-20$ & 13.992 \\
$21-30$ & 12.969 \\
$31-40$ & 10.591 \\
$41-50$ & 8.503 \\
$51-68$ & 1.856 \\
\hline
\end{tabular}

Table 4 shows that the maximum number of data overlaps occurring in this Total Ecosystem Function map was 68, with a peak at 11-20 data sets overlapping.

\section{DISCUSSION}

The method applied demonstrated that is was possible to spatially locate where ecosystem functions are derived and show by way of data overlap a rough measure of relative significance. Reviewing literature and interpreting the available data sets allowed the spatial identification of the processes and components of ecosystems that are providing ecosystem functions across the SEQ region, and therefore have the potential to provide high amounts of specific or multiple ecosystem services.
The review of available data indicated that although there were significant gaps in required information, there were sufficient data sets available for the mapping. When required and possible, new data sets were developed to fill these gaps. As most of the newly derived data sets contributed to four or more function maps it is evident these new data sets played a significant role in bridging these gaps, making a powerful contribution to presenting the individual functions. While there were not sufficient data to indicate the magnitude of the functions provided there was sufficient research or general principles in the literature to establish the rationale for using particular data sets for each function.

Fifteen (15) of the ecosystem function layers had greater than $40 \%$ of their mapped area (the SEQ region) covered with two or more data sets. No ecosystem function maps had an overlap of data areas cover greater than $70 \%$ of the mapped area. These results indicate the importance of the individual data layers and the need to use multiple surrogates to get the most comprehensive coverage of areas and to represent all the different pathways in which the same ecosystem function can be performed. With only a few exceptions, the areas that had the highest data overlap in the individual function maps all occupied only a small fraction of the total area.

Research into whether higher data overlap equates to a higher magnitude of actual ecosystem function has recently been conducted (S. Maynard R. Runting, M. Petter, S. Mooney, and A. Davidson, Synthesizing expert knowledge and GIS data sets to support an ecosystem services assessment framework, unpublished manuscript). Results indicate a strong relationship between high amounts of data overlap and magnitude of function, however, there can be no doubt that a lack of data will lead to less data overlaps occurring when using this method. This can be seen by the results for coastal and marine areas. Hotspots of coastal and marine ecosystem function have been identified but because of data gaps these areas have less total ecosystem function overlap than terrestrial areas. So, in addition to the maps providing some representation of ecosystem function, they also represent the state of our knowledge in these areas that can guide priorities for further data acquisition.

Also, lack of data overlap does not always indicate a lesser importance. The specific component of an ecosystem or pathway to that specific function (represented by a single data set) may be the most ecologically significant to maintaining that function in real world processes. This highlights the need for weighting of individual data layers and/or ecosystem functions in the context of the specific use intended (e.g., weighting the gas regulation function higher when applying to climate change mitigation and adaptation strategies). 
Some data sets were used in a larger number of ecosystem function maps (i.e., vegetation data sets such as good grass cover, detected woody vegetation, and wetlands) and so contributed more to the Total Ecosystem Function map.

When reviewing the two Total Ecosystem Function maps, Method B (Quartile) preserved high overlaps within ecosystem functions but lost areas with low data availability. Method A (Presence/Absence) was less sensitive to data gaps but failed to preserve information about high overlap areas within individual ecosystem functions. Consultations with decision makers and community ranked Method $\mathrm{A}$ as being more balanced and understandable. Ideally an overlap method that combines the strengths of both approaches is required.

It is important to recognize the limitations of GIS mapping. Among these limitations are biases in the geographic and temporal coverage of the data and in the types of data collected (Millennium Ecosystem Assessment 2005, Troy and Wilson 2006, Maynard et al. 2010). Data availability for some subregions in SEQ is greater than for others (e.g., marine areas), and there are differences between data availability for the various types of resources (e.g., biodiversity). Steps have been identified and others are being undertaken to narrow these differences. For example, to overcome the paucity of marine data one interim step would be to split all sea areas into at least three separate layers, benthic, pelagic, and sea surface in recognition of their distinct roles and the essentially threedimensional nature of the ocean.

\section{CONCLUSION}

The Millennium Ecosystem Assessment (MA) applied expert judgment to existing knowledge held by scientists, practitioners, and communities to address policy-relevant questions at global and subglobal scales (Millennium Ecosystem Assessment 2005). The SEQ project focused on local and regional scales and faced many of the same challenges identified in the broader-scale MA, i.e., data availability; bridging scales and knowledge systems of stakeholders; and ensuring the resulting products were sufficiently place-based and credible to meet the needs of decision makers.

The data sets that were applied and the resulting maps produced have been peer reviewed by the Steering Group, through an open forum of interested persons and organizations, predominantly SEQ stakeholders (the Working Group), and national and international conferences (Maynard et al. 2010). Overall the method produced maps that, when reviewed, were regarded as credible and useful. The mapping has helped strengthen government policy with respect to ecosystem services.

Ecosystem services and the SEQ Ecosystem Services Framework have been incorporated into the statutory planning document for the region: the SEQ Regional Plan 2009-2031.
Policy 4.3 (page 71) discusses the need to "Protect, maintain, and enhance the capacity of the region's ecosystems to supply ecosystem services". The ecosystem function maps are integral to the identification and measuring of ecosystem services to support this policy.

Other applications of the Framework and mapping products are as a Guiding Principle supporting the SEQ Natural Resource Management Plan 2009 - 2031 (Department of Environment and Resource Management 2009); Local Government Planning Schemes, Community Plans, Biodiversity and Nature Conservation Plans, and Water Resource Strategies. The method described for mapping ecosystem functions was used to generate two data sets for the SEQ State of the Region Report, one a map of ecosystem functions in 1991 and the other a change in ecosystem function map from 1991 to the present (Queensland Government 2008). Other potential applications include climate change mitigation and adaptation strategies and guiding the development of a regional offsetting program.

The project was limited in financial resources but fortunate to have some sound data sets and previous literature to draw upon, as well as expert and local knowledge. It is recognized that the SEQ region is relatively data rich, but key ingredients have been identified that would be required to apply this methodology to other regions, at the state-level or nationally.

The Framework remains nonprescriptive so stakeholders are able to apply the information to their management practices within their own capacities. Future work by SEQ Catchments will use these ecosystem function layers as feedstock for the production of ecosystem service maps.

Responses to this article can be read online at: http://www.ecologyandsociety.org/issues/responses. $\mathrm{php} / 5260$

\section{Acknowledgments:}

The authors would like to thank the expert panelists and other participants who have been involved in the development of the SEQ Ecosystem Services Framework. They would also like to acknowledge the invaluable role played by the Brisbane Region Environment Council. A particular thank you to David James and Melissa Walker for sharing their time and expertise in the development and review of this article.

\section{LITERATURE CITED}

Abel, N., J. Baxter, A. Campbell, H. Cleugh, J. Fargher, R. Lambeck, R. Prinsley, M. Prosser, R. Reid, G. Revell, C. Schmidt, R. Stirzaker, and P. Thorburn. 1997. Design principles for farm forestry: a guide to assist farmers to decide 
to place trees and farm plantations on farms. Rural Industries Research and Development Corporation, Barton, Australian Capital Territory, Australia.

Arshad, M. A., and S. Martin. 2002. Identifying critical limits for soil quality indicators in agro-ecosystems. Agriculture, Ecosystems \& Environment 88:153-160. http://dx.doi. org/10.1016/S0167-8809(01)00252-3

Arthington, A. H., and B. J. Pusey. 2003. Flow restoration and protection in Australian rivers. River Research and Applications 19:377-395. http://dx.doi.org/10.1002/rra.745

Australian Bureau of Statistics. 2010. Regional population growth, Australia, 2008-09. Australian Bureau of Statistics, Canberra, Australia.

Batker, D., E. Barclay, R. Boumans, and T. Hathaway. 2005. Ecosystem services enhanced by salmon habitat conservation in the Green/Duwamish and Central Puget Sound watershed. Asia Pacific Environmental Exchange, Seattle, Washington, USA.

Beeson, C. E., and P. F. Doyle. 1995. Comparison of bank erosion at vegetated and non-vegetated channel bends. Water Resources Bulletin 31(6):983-990. http://dx.doi.org/10.1111/ j.1752-1688.1995.tb03414.x

Belsky, A. J. 1994. Influences of trees on savanna productivity: tests of shade, nutrients, and tree-grass competition. Ecology 75:922-922. http://dx.doi.org/10.2307/1939416

Bennett, A. F. 1990. Habitat corridors and the conservation of small mammals in a fragmented forest environment. Landscape Ecology 4:109-122. http://dx.doi.org/10.1007/ $\underline{\mathrm{BF} 00132855}$

Bennett, E. M., and J. Alcamo. 2004. Ecosystems and human well-being: a framework for assessment. Island Press, Washington D.C., USA.

Bolund, P., and S. Hunhammar. 1999. Ecosystem services in urban areas. Ecological Economics 29:293-301. http://dx.doi. org/10.1016/S0921-8009(99)00013-0

Bormann, F. H., and G. E. Likens. 1967. Nutrient cycling. Science 155:424-429. http://dx.doi.org/10.1126/science.155.3761.424

Brooks, T. M., R. A. Mittermeier, C. G. Mittermeier, G. A. B. Da Fonseca, A. B. Rylands, W. R. Konstant, P. Flick, J. Pilgrim, S. Oldfield, G. Magin, and C. Hilton-Taylor. 2002. Habitat loss and extinction in the hotspots of biodiversity. Conservation Biology 16:909-923. http://dx.doi.org/10.1046/ j.1523-1739.2002.00530.x

Broome, S. W., E. D. Seneca, and W. W. Woodhouse Jr. 1988. Tidal salt marsh restoration. Aquatic Botany 32:1-22. http:// dx.doi.org/10.1016/0304-3770(88)90085-X

Bunn, S. E., P. M. Davies, and T. D. Mosisch. 1999. Ecosystem measures of river health and their response to riparian and catchment degradation. Freshwater Biology 41:333-345. http://dx.doi.org/10.1046/j.1365-2427.1999.00434.x

Butler, A., and P. Jernakoff. 1999. Seagrass in Australia: strategic review and development of an $R \& D$ plan. CSIRO Publishing, Collingwood, Victoria, Australia.

Carlson, T., and S. T. Arthur. 2000. The impact of land use land cover changes due to urbanization on surface microclimate and hydrology: a satellite perspective. Global and Planetary Change 25:49-65. http://dx.doi.org/10.1016/ S0921-8181(00)00021-7

Chisholm, S. W., P. G. Falkowski, and J. J. Cullen. 2001. Discrediting ocean fertilization. Science 294:309-310. http://dx. doi.org/10.1126/science.1065349

Chivian, E., editor. 2002. Biodiversity: its importance to human health. Second edition. Center for Health and the Global Environment, Harvard Medical School, Boston, Massachusetts, USA.

Clouston, E. M. 2002. Linking the ecological and economic values of wetlands: a case study of the wetlands of Moreton Bay. Griffith University, Brisbane, Australia.

Coles, R., L. McKenzie, S. Campbell, J. Mellors, M. Waycott, and L. Goggin. 2004. Seagrasses in Queensland waters. CRC Reef Research Centre Limited, Townsville, Queensland, Australia.

Committee on the Status of Pollinators in North America. 2007. Status of pollinators in North America. National Academies Press, Washington, D.C., USA.

Cork, S., D. Shelton, C. Binning, and R. Parry, editors. 2001. A framework for applying the concept of ecosystem services to natural resource management in Australia. CSIRO Sustainable Ecosystems, Victoria, Australia.

Corstanje, R., K. R. Reddy, J. P. Prenger, S. Newman, and A. V. Ogram. 2007. Soil microbial eco-physiological response to nutrient enrichment in a sub-tropical wetland. Ecological Indicators 7:277-289. http://dx.doi.org/10.1016/j.ecolind.2006.02.002

Corvalán, C., S. Hales, and A. J. McMichael. 2005. Ecosystems and human well-being: health synthesis. World Health Organisation, Geneva, Switzerland.

Costanza, R., R. d'Arge, R. de Groot, S. Farber, M. Grasso, B. Hannon, K. Limburg, S. Naeem, R. V. O'Neill, J. Paruelo, R. G. Raskin, P. Sutton, and M. van den Belt. 1997. The value of the world's ecosystem services and natural capital. Nature 387:253-260. http://dx.doi.org/10.1038/387253a0

Costanza, R., M. A. Wilson, A. Troy, A. Voinov, S. Liu, and J. D'Aagostino. 2006. The value of New Jersey's ecosystem services and natural capital. Springer Science \& Business Media, Netherlands; New York, USA. 
Cowling, R. M., B. Egoh, A. T. Knight, P. J. O'Farrell, B. Reyers, M. Rouget, D. J. Roux, A. Welz, and A. WilhelmRechman. 2008. An operational model for mainstreaming ecosystem services for implementation. Proceedings of the National Academy of Sciences 105:9483-9488. http://dx.doi. org/10.1073/pnas.0706559105

Cronk, J. K., and M. S. Fennessey. 2001. Wetland plants: biology and ecology. Lewis Publishers, Boca Raton, Florida, USA. http://dx.doi.org/10.1201/9781420032925

Cunningham, S. D., W. R. Berti, and J. W. Huang. 1995. Phytoremediation of contaminated soils. Trends in Biotechnology 13:393-397. http://dx.doi.org/10.1016/S0167-7799 (00)88987-8

Cunningham, S. A., F. FitzGibbon, and T. A. Heard. 2002. The future of pollinators for Australian agriculture. Australian Journal of Agricultural Research 53:893-900. http://dx.doi. org/10.1071/AR01186

Dafni, A. 1992. Pollination ecology: a practical approach. Oxford University Press, Oxford, UK.

Dawson, A. G., and S. Shi. 2000. Tsunami deposits. Pure and Applied Geophysics 157:875-897. http://dx.doi.org/10.1007/ $\underline{\mathrm{s} 000240050010}$

de Groot, R. S., M. A. Wilson, and R. M. J. Boumans. 2002. A typology for the classification, description and valuation of ecosystem functions, goods and services. Ecological Economics 41:393-408. http://dx.doi.org/10.1016/S0921-8009 (02)00089-7

de Lacerda, L. D., editor. 2002. Mangrove ecosystems: function and management. Springer, Berlin, Germany.

Department of Agriculture, Fisheries and Forestry. 2003. Australian agriculture, fisheries and forestry at a glance. Commonwealth of Australia, Canberra, Australia.

Department of Environment and Resource Management (DERM). 2008. Queensland drainage basin (1:100,000 Scale). Department of Environment and Resource Management, Brisbane, Australia.

Department of Environment and Resource Management (DERM). 2009. The SEQ Natural Resource Management Plan 2009 - 2031. Queensland Government, Brisbane, Australia.

Department of Natural Resources and Mines (DNR\&M). 2002. SEQ Geological Units Database. Department of Natural Resources and Mines, Brisbane, Queensland, Australia.

Department of Natural Resources and Mines (DNR\&M). 2005. Land cover change in Queensland 2001-2003, incorporating 2001-2002 and 2002-2003 change periods: a statewide land-cover and trees study (SLATS) report, Feb. 2005. Department of Natural Resources and Mines, Brisbane, Australia.
Department of Natural Resources and Water (DNR\&W). 2006. Queensland dams and waterbodies. Department of Natural Resources and Water, Brisbane, Queensland, Australia.

Department of Primary Industries and Department of Housing, Local Government and Planning (DPI and DHLGP). 1993. Planning guidelines: the identification of good quality agricultural land. DPI/DHLGP, Brisbane, Queensland, Australia.

Environmental Protection Agency (EPA). 2002. Biodiversity assessment and mapping methodology. Environmental Protection Agency, Brisbane, Queensland, Australia.

Environmental Protection Agency (EPA). 2005. Queensland herbarium survey and mapping of 2003 remnant vegetation communities and regional ecosystems of Queensland. Environmental Protection Agency, Brisbane, Queensland, Australia.

Environmental Protection Agency (EPA). 2006a. Areas of coastal biodiversity significance (marine). South-east Queensland Regional Coastal Plan. Environmental Protection Agency, Brisbane, Queensland, Australia.

Environmental Protection Agency (EPA). 2006b. South-east Queensland regional coastal management plan. Environmental Protection Agency, Brisbane, Queensland, Australia.

Environmental Protection Agency (EPA). 2006c. South-east Queensland regional coastal management plan supporting document. Environmental Protection Agency, Brisbane, Queensland, Australia.

Environmental Protection Agency (EPA). 2007a. Moreton Bay marine park zoning plan review. Habitat information: mangroves. Environmental Protection Agency, Brisbane, Queensland, Australia.

Environmental Protection Agency (EPA). 2007b. WildNet (database). Environmental Protection Agency, Brisbane, Queensland, Australia.

Environmental Protection Agency (EPA). 2008. Queensland Wetlands Program - SEQ draft wetland mapping files. Environmental Protection Agency, Brisbane, Australia.

Farrier, D., and L. Tucker. 2001. Access to marine bioresources: hitching the conservation cart to the bioprospecting horse. Ocean Development \& International Law 32:213-239. http://dx.doi.org/10.1080/009083201750397583

Friedman, J., and L. D. Harder. 2004. Inflorescence architecture and wind pollination in six grass species. Functional Ecology 18:851-860. http://dx.doi.org/10.1111/ j.0269-8463.2004.00921.x 
Garrison, T. 2007. Oceanography: an invitation to marine science. Sixth edition. Thomson Brooks/Cole, Belmont, California, USA.

Geiger, R. 1965. The climate near the ground. Revised edition. Harvard University Press, Cambridge, Massachusetts, USA.

Gerrard, J. 1992. Soils geomorphology. Chapman \& Hall, New York, USA.

Getter, F. 1999. The role of plants in waste management. Agricultural waste management field handbook. United States Department of Agriculture. [online] URL: http://directives.sc. egov.usda.gov/OpenNonWebContent.aspx?content=6621.wba

Gleick, P. H. 1996. Basic water requirements for human activities: meeting basic needs. Water International 21:83-92.

Greenslade, P. 1992. Conserving invertebrate diversity in agricultural, forestry and natural ecosystems in Australia. Agriculture, Ecosystems \& Environment 40:297-312. http:// dx.doi.org/10.1016/0167-8809(92)90099-W

Hanson, H., A. Brampton, M. Capobianco, H. H. Dette, L. Hamm, C. Laustrup, A. Lechuga, and R. Spanhoff. 2002. Beach nourishment projects, practices, and objectives- a European overview. Coastal Engineering 47:81-111. http:// dx.doi.org/10.1016/S0378-3839(02)00122-9

Hassan, R., R. Scholes, and N. Ash, editors. 2005. Ecosystems and human well-being: current state and trends. Island Press, Washington, D.C., USA.

Hinchcliffe, S. 2009. South East Queensland regional plan 2009-2031. Queensland Department of Infrastructure and Planning, Brisbane, Australia.

Jenny, H. 1994. Factors of soil formation. A system of quantitative pedology. Dover Publications, New York, USA. http://dx.doi.org/10.1097/00010694-194111000-00009

Joffe, J.S.. 1949. Pedology. Pedology Publications, New Brunswick, New Jersey, USA.

Kadlec, R. H., and S. D. Wallace. 2008. Treatment wetlands. Second edition. CRC Press, Boca Raton, Florida, USA. http:// dx.doi.org/10.1201/9781420012514

Kavanagh, R., B. Law, F. Lemckert, M. Stanton, M. Chidel, T. Brassil, A. Towerton, and M. Herring. 2005. Biodiversity in Eucalypt plantings established to reduce salinity. Rural Industries Research and Development Corporation, Barton, Australian Capital Territory, Australia.

Kokic, P. 1993. Australian broadacre agriculture: forecasting supply at the farm level. Australian Bureau of Agricultural and Resource Economics, Canberra, Australia.
Kraufvelin, P. 2007. Responses to nutrient enrichment, wave action and disturbance in rocky shore communities. Aquatic Botany 87:262-274. http://dx.doi.org/10.1016/j.aquabot.2007.06.011

Kremen, C., and R. S. Ostfeld. 2005. A call to ecologists: measuring, analyzing, and managing ecosystem services. Frontiers in Ecology and the Environment 3:540-548. http:// dx.doi.org/10.1890/1540-9295(2005)003[0540:ACTEMA]2.0. $\mathrm{CO} ; 2$

Krieger, D. J. 2001. Economic value of forest ecosystem services: a review. The Wilderness Society, Washington, D. C., USA.

Laegdsgaard, P. 2006. Ecology, disturbance and restoration of coastal saltmarsh in Australia: a review. Wetlands Ecology and Management 14:379-399. http://dx.doi.org/10.1007/ s11273-005-8827-Z

Land Stewardship Project. 2004. Land stewardship project fact sheet \#15: how farms can improve water quality. Agriculture's multiple benefits. Land Stewardship Project, Minneapolis, Minnesota, USA.

Liu, S., R. Costanza, A. Troy, J. D'Aagostino, and W. Mates. 2010. Valuing New Jersey's ecosystem services and natural capital: a spatially explicit benefit transfer approach. Springer Science \& Business Media, Netherlands; New York, USA. http://dx.doi.org/10.1007/s00267-010-9483-5

Lloyd, J., and S. Cook. 2002. Australia-wide assessment of river health: Northern Territory AusRivAS sampling and processing manual. Commonwealth of Australia and Department of Lands, Planning and Environment, Canberra, Australian Capital Territory, Australia.

Lochte, K., W. Broadgate, and E. Urban. 2003. Ocean biogeochemistry and biology: a vision for the next decade of global change research. Global change newsletter 56:19-23

Lough, J. M. 1994. Climate variation and El Niño-Southern Oscillation events on the Great Barrier Reef: 1958 to 1987. Coral Reefs 13:181-185. http://dx.doi.org/10.1007/BF00301197

Lowe, A. J., D. Boshier, M. Ward, C. F. E. Bacles, and C. Navarro. 2005. Genetic resource impacts of habitat loss and degradation; reconciling empirical evidence and predicted theory for neotropical trees. Heredity 95:255-273. http://dx. doi.org/10.1038/sj.hdy.6800725

Maritime Safety Queensland. 2007. Soundings and contours. Queensland Government, Brisbane, Australia.

Maynard, S., D. James, and A. Davidson. 2010. The development of an ecosystem services framework for South East Queensland. Environmental Management 45:881-895. http://dx.doi.org/10.1007/s00267-010-9428-z 
Maynard, S., D. James, and A. Davidson. 2012. An adaptive participatory approach for developing an ecosystem services framework for South East Queensland, Australia. International Journal of Biodiversity Science, Ecosystem Services \& Management 7(3):182-189. http://dx.doi. org/10.1080/21513732.2011.652176

McInnes, K. L., K. J. E. Walsh, G. D. Hubbert, and T. Beer. 2003. Impact of sea-level rise and storm surges on a coastal community. Natural Hazards 30:187-207. http://dx.doi. org/10.1023/A:1026118417752

Millennium Ecosystem Assessment. 2005. Ecosystems and human well-being: our human planet: summary for decisionmakers. Island Press, Washington, D.C., USA.

Milly, P. C. D., and K. A. Dunne. 1994. Sensitivity of the global water cycle to the water-holding capacity of land. Journal of Climate 7:506-526. http://dx.doi.org/10.1175/1520-0442 (1994)007<0506:SOTGWC>2.0.CO;2

Moreton Bay Waterways and Catchments Partnership (MBWCP). 2005. Ecosystem health monitoring program EcoHplots spring 2004 and autumn 2005 (all SEQ EHMP sites). Healthy Waterways, Brisbane, Queensland, Australia.

Morrison, M. L., B. G. Marcot, and R. W. Mannan. 2006. Wildlife-habitat relationships: concepts and applications. Island Press, Washington, D.C., USA.

Murcia, C. 1995. Edge effects in fragmented forests: implications for conservation. Trends in Ecology \& Evolution 10:58-62. http://dx.doi.org/10.1016/S0169-5347(00)88977-6

Murphy, B., and D. Nance. 2000. Earth science today. Brooks/ Cole, California, USA.

Naiman, R. J., and H. Décamps. 1997. The ecology of interfaces: riparian zones. Annual Review of Ecology and Systematics 28:621-658. http://dx.doi.org/10.1146/annurev. ecolsys.28.1.621

Neal, B., P. Erlanger, R. Evans, A. Kollmorgen, J. Ball, M. Shirley, and L. Donnelley. 2007. Inland waters theme report. Department of the Environment, Water, Heritage and the Arts, Victoria, Australia.

Newbold, J. D., J. W. Elwood, R. V. O'Neill, and W. V. Winkle. 1981. Measuring nutrient spiralling in streams. Canadian Journal of Fisheries and Aquatic Sciences 38:860-863. http://dx.doi.org/10.1139/f81-114

Office of Urban Management. 2007. South East Queensland regional plan 2005-2026 implementation guideline no. 8: identifying and protecting scenic amenity values. Queensland Government, Department of Infrastructure, Queensland, Australia.

Park, C. C. 2001. The environment: principles and applications. Routledge, London, UK.
Parkes, D., G. Newell, and D. Cheal. 2003. Assessing the quality of native vegetation: the 'habitat hectares' approach. Ecological Management \& Restoration 4:S29-S38. http://dx. doi.org/10.1046/j.1442-8903.4.s.4.x

Paulus, B. C., J. Kanowski, P. A. Gadek, and K. D. Hyde. 2006. Diversity and distribution of saprobic microfungi in leaf litter of an Australian tropical rainforest. Mycological Research 110:1441-1454. http://dx.doi.org/10.1016/j. mycres.2006.09.002

Phillips, N. 2006. Freshwater ecosystems: functional biodiversity in streams. Water \& Atmosphere 14(1):22-23.

Phillips, J. D., M. C. Slattery, and P. A. Gares. 1999. Truncation and accretion of soil profiles on coastal plain croplands: implications for sediment redistribution. Geomorphology 28:119-140. http://dx.doi.org/10.1016/S0169-555X (98)00105-6

Pihl, L. 1985. Food selection and consumption of mobile epibenthic fauna in shallow marine areas. Marine Ecology Progress Series 22:169-179. http://dx.doi.org/10.3354/ meps022169

Preston, R. 2001. Scenic amenity: measuring community appreciation of landscape aesthetics at Moggill and Glen Rock. Department of Natural Resources and Mines and Environmental Protection Agency, Brisbane, Queensland, Australia.

Prosser, I. P., A. O. Hughes, and I. D. Rutherfurd. 2000. Bank erosion of an incised upland channel by subaerial processes: Tasmania, Australia. Earth Surface Processes and Landforms 25:1085-1101.http://dx.doi.org/10.1002/1096-9837(200009) 25:10<1085::AID-ESP118>3.0.CO $2-\mathrm{K}$

Queensland Fisheries Service- Marine Habitat. 2000. Metadata for fish habitat areas - Queensland. Queensland Fisheries Service, Brisbane, Queensland, Australia.

Queensland Government. 1997. Marine parks (Moreton Bay) zoning plan 1997. Queensland Government, Queensland, Australia.

Queensland Government. 2003. Regional nature conservation strategy for South East Queensland 2003 - 2009. Environmental Protection Agency, Brisbane, Queensland, Australia.

Queensland Government. 2008. South East Queensland state of the region report 2008. Queensland Government, Queensland, Australia.

Rabus, B., M. Eineder, A. Roth, and R. Bamler. 2003. The shuttle radar topography mission- a new class of digital elevation models acquired by spaceborne radar. ISPRS Journal of Photogrammetry and Remote Sensing 57:241-262. http://dx.doi.org/10.1016/S0924-2716(02)00124-7 
Rapport, D. J., C. Gaudet, J. R. Karr, J. S. Baron, C. Bohlen, W. Jackson, B. Jones, R. J. Naiman, B. Norton, and M. M. Pollock. 1998. Evaluating landscape health: integrating societal goals and biophysical process. Journal of Environmental Management 53:1-15. http://dx.doi.org/10.1006/ jema.1998.0187

Reichelt, J. L., and M. A. Borowitzka. 1984. Antimicrobial activity from marine algae: results of a large-scale screening programme. Hydrobiologia 116-117:158-168. http://dx.doi. org/10.1007/BF00027657

Reynolds, S. G., and J. Frame, editors. 2005. Grasslands: developments, opportunities, perspectives. Food and Agricultural Organization and Science Publishers, Rome, Italy; and Plymouth, UK.

Richardson, J. L., and M. J. Vepraskas, editors. 2001. Wetland soils: genesis, hydrology, landscapes, and classification. Lewis Publishers, Boca Raton, Florida, USA.

Roberts, D., T. Dowling, and J. Walker. 1997. FLAG: a fuzzy landscape analysis method for dryland salinity assessment. CSIRO Land and Water, Canberra, Australia.

Roberts, C. M., C. J. McClean, J. E. N. Veron, J. P. Hawkins, G. R. Allen, D. E. McAllister, C. G. Mittermeier, F. W. Schueler, M. Spalding, F. Wells, C. Vynne, and T. B. Werner. 2002. Marine biodiversity hotspots and conservation priorities for tropical reefs 295:1280-1284. http://dx.doi. org/10.1126/science.1067728

Rogers, K., N. Saintilan, and H. Heijnis. 2005. Mangrove encroachment of salt marsh in Western Port Bay, Victoria: the role of sedimentation, subsidence, and sea level rise. Estuaries 28:551-559. http://dx.doi.org/10.1007/BF02696066

Sanchirico, J. N, and P. J. Mumby. 2009. Mapping ecosystem functions to the valuation of ecosystem services: implications of species-habitat associations for coastal land-use decisions. Theoretical Ecology 2:67-77. http://dx.doi.org/10.1007/ s12080-008-0034-0

Scarth P., M. Byrne, T. Danaher, B. Henry, R. Hassett, J. Carter, and P. Timmers. 2006. State of the paddock: monitoring condition and trend in groundcover across Queensland. 13th Australasian Remote Sensing and Photogrammetry Conference, Canberra, Australia, 20 - 24 November 2006. http://dx.doi.org/10.6084/m9.figshare.94248

Schneider, F. I., and K. H. Mann. 1991. Species specific relationships of invertebrates to vegetation in a seagrass bed. I. Correlational studies. Journal of Experimental Marine Biology and Ecology 145:101-117. http://dx.doi. org/10.1016/0022-0981(91)90008-K

Schnitzer, M., and S. U. Khan, editors. 1978. Soil organic matter. Elsevier, Amsterdam, Netherlands; New York, USA.
Scholes, M. C., P. A. Matrai, M. O. Andreae, K. A. Smith, and M. R. Manning. 2003. Chapter 2: Biosphere-atmosphere reactions. Pages 19 - 72 in G. P. Brasseur, R. G. Prinn, and A. A. P. Pszenny, editors. Atmospheric chemistry in a changing world: an integration and synthesis of a decade of tropospheric chemistry research. Springer Publishing, Berlin, Germany. http://dx.doi.org/10.1007/978-3-642-18984-5_2

Serfling, R. J. 1980. Approximation theorems of mathematical statistics. John Wiley \& Sons, New York, USA. http://dx.doi. org/10.1002/9780470316481

Shelton, D., S. S. Cork, C. Binning, R. Parry, P. Hairsine, R. Vertessy, and M. Stauffacher. 2001. Application of an ecosystem services inventory approach to the Goulburn Broken catchment. Pages 157-162 in I. Rutherford, F. Sheldon, G. Brierley, and C. Kenyon, editors. Proceedings of the Third Australian Stream Management Conference. Cooperative Research Centre for Catchment Hydrology, Brisbane, Queensland, Australia.

South East Queensland Regional Organisation of Councils. 2005. What's in a view? Report 1: Overview of the Scenic SEQ 2004 Public Preference Survey. Office of Urban Management, Brisbane, Australia.

South East Queensland Healthy Waterways Partnership. 2007. South East Queensland healthy waterways strategy 2007-2012. Healthy Waterways, Brisbane, Queensland, Australia.

Sturges, W. T., K. N. Bower, T. W. Choularton, K. S. Law, P. S. Liss, S. A. Penkett, J. M. C. Plane, and C. E. Reeves, editors. 2001. Atmospheric chemistry studies in the oceanic environment: achievements and scientific highlights. Natural Environment Research Council, Swindon, United Kingdom.

Suppiah, R., and K. J. Hennessy. 1998. Trends in total rainfall, heavy rain events and number of dry days in Australia, 1910 1990. International Journal of Climatology 18:1141-1164. http://dx.doi.org/10.1002/(SICI)1097-0088(199808)18:10<1141:: AID-JOC286>3.0.CO;2-P

Terranean Mapping Technologies. 2007. Land cover mapping of Southeast Queensland catchments area. Terranean Mapping Technologies, Brisbane, Queensland, Australia.

Tockner, K., D. Pennetzdorfer, N. Reiner, F. Schiemer, and J. V. Ward. 1999. Hydrological connectivity, and the exchange of organic matter and nutrients in a dynamic river-floodplain system (Danube, Austria). Freshwater Biology 41:521-535. http://dx.doi.org/10.1046/j.1365-2427.1999.00399.x

Tomlinson, P. B. 1994. The botany of mangroves. Cambridge University Press, Cambridge, UK.

Troy, A., and M. A. Wilson. 2006. Mapping ecosystem services: practical challenges and opportunities in linking GIS 
and value transfer. Ecological Economics 60:435-449. http:// dx.doi.org/10.1016/j.ecolecon.2006.04.007

United States Army Corps of Engineers. 1989. Environmental engineering for coastal protection. United States Army Corps of Engineers, Washington, D.C., USA.

United States Environmental Protection Agency, Office of Wetlands, Oceans and Watersheds. 2006. Wetlands: protecting life and property from flooding. United States Environmental Protection Agency, Washington, D. C., USA.

United States National Geospatial Intelligence Agency (USNGIA). 2005. Shuttle radar topography mission digital elevation model. U.S. National Geospatial Intelligence Agency, Washington, D.C., USA.

Velz, C. J. 1970. Applied stream sanitation. WileyInterscience, New York, USA.

Volkman, J. K. 1999. Australasian research on marine natural products: chemistry, bioactivity and ecology. Marine and Freshwater Research 50:761-779. http://dx.doi.org/10.1071/ MF99084

Warburton, K., and S. J. M. Blaber. 1992. Patterns of recruitment and resource use in a shallow-water fish assemblage in Moreton Bay, Queensland. Marine Ecology Progress Series 90:113-126. http://dx.doi.org/10.3354/ $\underline{\text { meps090113 }}$

WBM Oceanics. 2004. SEQ streams and catchments. WBM Oceanics, Brisbane, Australia.

WBM Oceanics. 2005. Sub catchment mean loads (SEQ EMSS modelling program). WBM Oceanics, Brisbane, Australia.

White, D. H., and L. Karssies. 1999. Australia's national drought policy. Aims, analyses and implementation. Water International 24:2-9. http://dx.doi.org/10.1080/02508069908692128

Whiting, G. J., and J. P. Chanton. 2001. Greenhouse carbon balance of wetlands: methane emission versus carbon sequestration. Tellus B 53:521-528. http://dx.doi.org/10.1034/ j.1600-0889.2001.530501.x

Williams, J., C. Read, T. Norton, S. Dovers, M. Burgman, W. Proctor, and H. Anderson. 2001. Biodiversity. Department of the Environment and Heritage, Canberra, Australia.

Witte, C., D. van den Berg, T. Rowland, T. O’Donnell, R. Denham, G. Pitt, and J. Simpson. 2006. Mapping land use in Queensland - technical report on the 1999 land use map for Queensland. Department of Natural Resources, Mines and Water, Brisbane, Queensland, Australia.

Young, A. 1989. Agroforestry for soil conservation. C.A.B. International, Wallingford, UK.

Young, P., and H. Dillewaard. 1999. Southeast Queensland. Pages 1 - 75 in P. Sattler, and R. Williams, editors. The conservation status of Queensland's bioregional ecosystems. Environmental Protection Agency, Brisbane, Queensland, Australia.

Zimmermann, C., R. Dean, V. Penchev, and H. Verhagen, editors. 2005. Environmentally friendly coastal protection. Springer, Dordrecht, Netherlands. http://dx.doi.

org/10.1007/1-4020-3301-X 


\section{APPENDIX 1}

Table A1.1. List of Ecosystem Functions and their descriptions as incorporated into the SEQ Ecosystem Services Framework

\begin{tabular}{|c|c|c|}
\hline $\begin{array}{l}\text { Function } \\
\text { Categories }\end{array}$ & $\begin{array}{l}\text { Ecosystem } \\
\text { Function }\end{array}$ & $\begin{array}{l}\text { Description - ecosystem processes and components } \\
\text { (Ecological Complexity) }\end{array}$ \\
\hline \multirow{10}{*}{$\begin{array}{l}\text { Regulating } \\
\text { Functions } \\
\text { Maintenance of } \\
\text { essential ecological } \\
\text { processes and life } \\
\text { support systems. }\end{array}$} & (1) Gas regulation & $\begin{array}{l}\text { Relates to the influence of natural and managed systems in relation to biogeochemical } \\
\text { processes including greenhouse gases, photo-chemical smog and volatile organic compounds } \\
\text { (VOCs). }\end{array}$ \\
\hline & (2) Climate regulation & $\begin{array}{l}\text { Influence of land cover and biological mediated processes that regulate atmospheric processes } \\
\text { and weather patterns which in turn create the microclimate in which different plants and animals } \\
\text { (incl. humans) live and function. }\end{array}$ \\
\hline & $\begin{array}{l}\text { (3) Disturbance } \\
\text { regulation }\end{array}$ & $\begin{array}{l}\text { The capacity of the soil, regolith and vegetation to buffer the effects of wind, water and waves } \\
\text { through water and energy storage capacity and surface resistance. The soil profile stores water } \\
\text { and reduces runoff. Vegetation enhances infiltration and provides surface resistance. Degraded } \\
\text { soils and landscapes have a reduced capacity. Soil properties (e.g. depth, surface texture) and } \\
\text { vegetation structure are important. }\end{array}$ \\
\hline & (4) Water regulation & $\begin{array}{l}\text { The influence of land cover, topography, soils, hydrological conditions in the spatial and } \\
\text { temporal distribution of water through atmosphere, soils, aquifers, rivers, lakes and wetlands }\end{array}$ \\
\hline & (5) Soil retention & Minimising soil loss through having adequate vegetation cover, root biomass and soil biota. \\
\hline & (6) Nutrient regulation & The role of ecosystems in the transport, storage and recycling of nutrients. \\
\hline & $\begin{array}{l}\text { (7) Waste treatment } \\
\text { and assimilation }\end{array}$ & $\begin{array}{l}\text { The extent to which ecosystems are able to transport, store and recycle certain excesses of } \\
\text { organic and inorganic wastes through distribution, assimilation, transport and chemical } \\
\text { recomposition. }\end{array}$ \\
\hline & (8) Pollination & $\begin{array}{l}\text { Pollination is critical to the reproduction of most wild plants and the production of food for } \\
\text { consumption by animals and humans. Pollination is the interaction between plants and (1) } \\
\text { biotic vectors e.g. insects, birds and mammals and (2) abiotic vectors e.g. wind and water in the } \\
\text { movement of male gametes for plant production. Pollination and seed dispersal are linked. }\end{array}$ \\
\hline & (9) Biological control & $\begin{array}{l}\text { The interactions within biotic communities that act as restraining forces to control population of } \\
\text { potential pests and disease vectors. This function consists of natural and biological control } \\
\text { mechanisms. }\end{array}$ \\
\hline & $\begin{array}{l}\text { (10) Barrier effect of } \\
\text { vegetation }\end{array}$ & $\begin{array}{l}\text { Vegetation impedes the movement of airborne substances such as dust and aerosols (including } \\
\text { agricultural chemicals and industrial and transport emissions), enhances air mixing and } \\
\text { mitigates noise. }\end{array}$ \\
\hline \multirow{2}{*}{$\begin{array}{l}\text { Supporting } \\
\text { Functions } \\
\\
\text { Providing habitat } \\
\text { (suitable living space) } \\
\text { for wild plant and animal } \\
\text { species at local and } \\
\text { regional scales. }\end{array}$} & $\begin{array}{l}\text { (11) Supporting } \\
\text { habitats }\end{array}$ & $\begin{array}{l}\text { Preservation of natural and semi natural ecosystems as suitable living space for wild biotic } \\
\text { communities and individual species. Natural ecosystems are a storehouse of genetic } \\
\text { information generated through evolutionary process. This function also includes the provision of } \\
\text { suitable breeding, reproduction, nursery and refugia and corridors (connectivity) for species that } \\
\text { are harvested or otherwise valued. }\end{array}$ \\
\hline & (12) Soil Formation & $\begin{array}{l}\text { Soil formation is the facilitation of soil formation processes. Soil formation processes include the } \\
\text { chemical weathering of rocks and the transportation and accumulation of inorganic and organic } \\
\text { matter. }\end{array}$ \\
\hline \multirow{6}{*}{$\begin{array}{l}\text { Provisioning } \\
\text { Functions } \\
\text { Provision of natural } \\
\text { resources. }\end{array}$} & (13) Food & $\begin{array}{l}\text { Biomass that sustains living organisms. Material that can be converted to provide energy and } \\
\text { nutrition. Mostly initially derived from photosynthesis. }\end{array}$ \\
\hline & (14) Raw materials & Biomass that is used for any purpose other than food (excluding mining resources). \\
\hline & (15) Water supply & $\begin{array}{l}\text { The role of ecosystems in providing water through sediment trapping, infiltration, dissolution, } \\
\text { precipitation and diffusion. }\end{array}$ \\
\hline & (16) Genetic resources & $\begin{array}{l}\text { Self maintaining diversity of organisms developed over evolutionary time (capable of continuing } \\
\text { to change). Measurable at species, molecular and sub molecular levels. These processes are } \\
\text { increasingly paralleled by human intervention. }\end{array}$ \\
\hline & $\begin{array}{l}\text { (17) Provision of shade } \\
\text { and shelter }\end{array}$ & $\begin{array}{l}\text { Relates to vegetation that ameliorates extremes in weather and climate at a local landscape } \\
\text { scale. Shade or shelter is important for plants, animals and structures. }\end{array}$ \\
\hline & $\begin{array}{l}\text { (18) Pharmacological } \\
\text { resources }\end{array}$ & $\begin{array}{l}\text { Natural materials that are or can be used by organisms to maintain, restore or improve health. } \\
\text { (Natural patterns can be copied by humans for synthetic products). }\end{array}$ \\
\hline $\begin{array}{l}\text { Functions } \\
\text { Providing life fulfilment } \\
\text { opportunities and } \\
\text { cognitive development } \\
\text { through exposure to life } \\
\text { processes and natural } \\
\text { systems. }\end{array}$ & $\begin{array}{l}\text { (19) Landscape } \\
\text { opportunity }\end{array}$ & $\begin{array}{l}\text { The inspiration and motivation, traditional owner and other cultural, historical and aesthetic } \\
\text { values; health enhancement; sense of place; amenity; recreational, scientific and educational } \\
\text { opportunity, provided by the extent and variety of natural features and landscapes. }\end{array}$ \\
\hline
\end{tabular}




\section{APPENDIX 2}

Table A2.1. Data sets used and a description of the contribution of each data set to a component of ecosystem function.

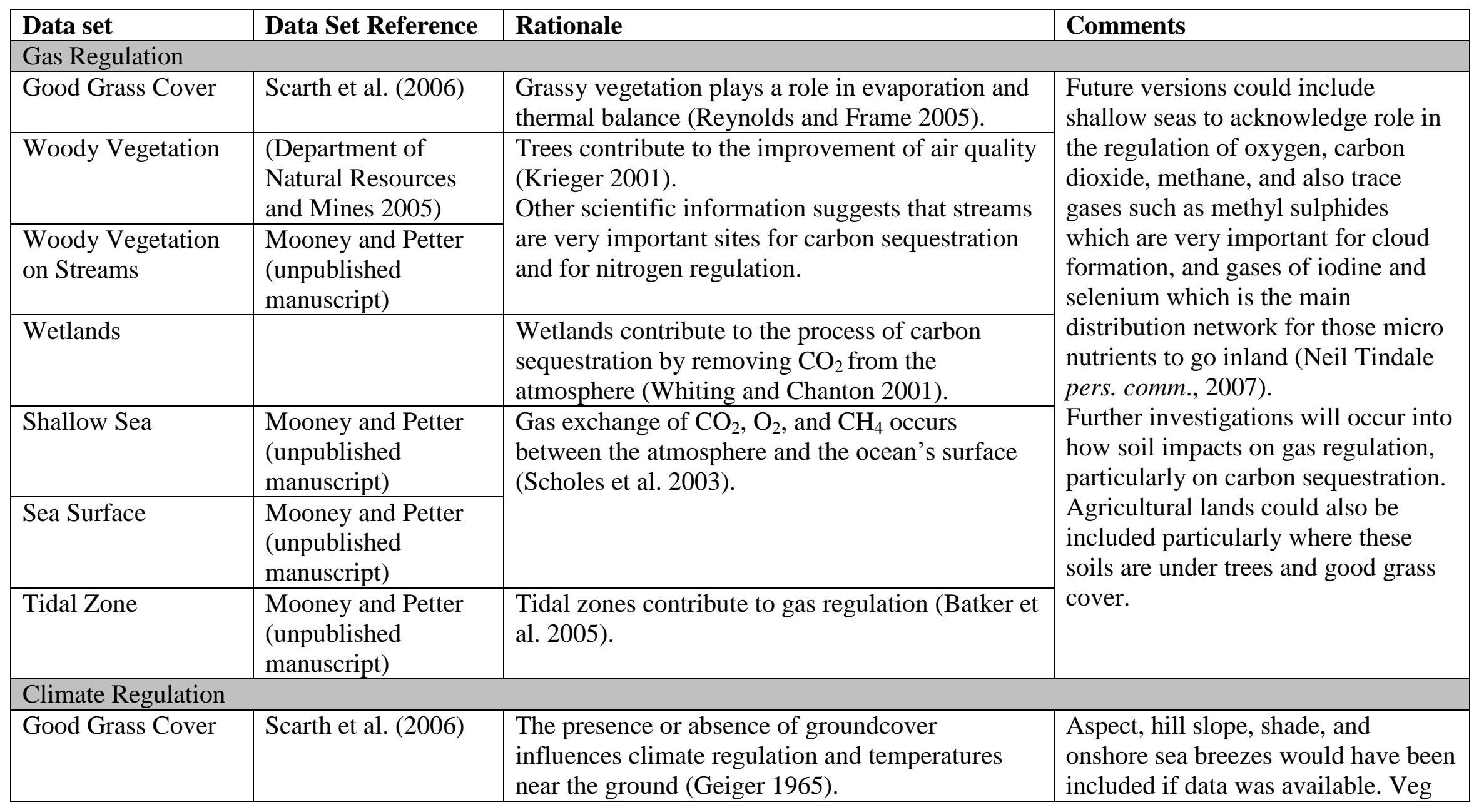




\begin{tabular}{|c|c|c|c|}
\hline Data set & Data Set Reference & Rationale & Comments \\
\hline Woody Vegetation & Scarth et al. (2006) & $\begin{array}{l}\text { Trees create an area where climate regulation } \\
\text { occurs under the canopy (Geiger 1965). }\end{array}$ & \multirow{3}{*}{$\begin{array}{l}\text { mapping was used as a surrogate. } \\
\text { There is evidence that modified } \\
\text { systems such as cropping/irrigated } \\
\text { land can have a cooling effect (Abel } \\
\text { et al. 1997), as can water bodies and } \\
\text { dams (Park 2001). } \\
\text { The good grass cover and woody veg } \\
\text { layers have been used as surrogates } \\
\text { for climate regulation. This is } \\
\text { distinct from gas and } \mathrm{CO}^{2} \text { regulation } \\
\text { (Sturges et al. 2001), and other } \\
\text { elements of climate regulation which } \\
\text { are covered by other functions. }\end{array}$} \\
\hline Rainfall & $\begin{array}{l}\text { Mooney and Petter } \\
\text { (unpublished } \\
\text { manuscript) }\end{array}$ & $\begin{array}{l}\text { Rainfall is an indicator of climate variability } \\
\text { (Lough 1994). }\end{array}$ & \\
\hline Sea Surface & $\begin{array}{l}\text { Mooney and Petter } \\
\text { (unpublished } \\
\text { manuscript) }\end{array}$ & $\begin{array}{l}\text { Oceans play a key role in the global carbon cycle } \\
\text { and climate regulation (Chisholm et al. 2001). }\end{array}$ & \\
\hline \multicolumn{4}{|c|}{ Disturbance Regulation } \\
\hline $\begin{array}{l}\text { Mangroves, } \\
\text { Samphire and Salt } \\
\text { Marshes }\end{array}$ & $\begin{array}{l}\text { EPA (Young and } \\
\text { Dillewaard 1999) }\end{array}$ & $\begin{array}{l}\text { Mangroves provide buffers to floods and storm } \\
\text { surges and protect coast lines from erosion } \\
\text { (Tomlinson 1994). Mangroves provide storm } \\
\text { protection (Bennett and Alcamo 2004). Salt } \\
\text { marshes provide protection against disturbance } \\
\text { events (Laegdsgaard 2006). }\end{array}$ & \multirow[t]{3}{*}{$\begin{array}{l}\text { Evidence from the Millennium } \\
\text { Ecosystem Assessment Report on } \\
\text { Ecosystems and Human Well-Being } \\
\text { suggests that reefs provide storm } \\
\text { protection and can reduce impacts of } \\
\text { hurricanes and tidal waves (Bennett } \\
\text { and Alcamo 2004). }\end{array}$} \\
\hline Good Grass Cover & Scarth et al. (2006) & $\begin{array}{l}\text { Contributes to dune and bank stabilization (United } \\
\text { States Army Corps of Engineers 1989). }\end{array}$ & \\
\hline $\begin{array}{l}\text { Land Below } 5 \\
\text { Metres HAT }\end{array}$ & $\begin{array}{l}\text { NASA Shuttle Radar } \\
\text { Typography Mission } \\
\text { (Rabus et al. 2003), } \\
\text { with DNR\&M for } \\
\text { use in this project (P } \\
\text { Scarth 2007, pers. } \\
\text { comm., 22 March). }\end{array}$ & $\begin{array}{l}\text { Coastal areas within this layer have been exposed } \\
\text { to disturbances in the past. For example, there is } \\
\text { geological evidence that a large tsunami } \\
\text { previously hit the south east coast of Australia } \\
\text { (Dawson and Shi 2000), indicating that this area } \\
\text { is prone to possible further disturbances. }\end{array}$ & \\
\hline
\end{tabular}




\begin{tabular}{|c|c|c|c|}
\hline Data set & Data Set Reference & Rationale & Comments \\
\hline Coastal Dunes & $\begin{array}{l}\text { Mooney and Petter } \\
\text { (unpublished } \\
\text { manuscript) }\end{array}$ & $\begin{array}{l}\text { Dunes provide protection from coastal erosion } \\
\text { processes including wind, waves and storm surges } \\
\text { (Zimmermann et al. 2005). }\end{array}$ & \\
\hline SEQ Water Bodies & $\begin{array}{l}\text { Department of } \\
\text { Environment and } \\
\text { Resource } \\
\text { Management } \\
\text { (DERM 2008) }\end{array}$ & $\begin{array}{l}\text { Lakes and dams store water and can reduce } \\
\text { flooding by taking on excess flood waters and } \\
\text { runoff thereby reducing their impact (Neal et al. } \\
\text { 2007). }\end{array}$ & \\
\hline Woody Vegetation & DNR\&M (2005) & \multirow{4}{*}{$\begin{array}{l}\text { Trees provide disturbance regulation by providing } \\
\text { shelter from strong winds and conserving soils } \\
\text { (Abel et al. 1997). }\end{array}$} & \\
\hline $\begin{array}{l}\text { Woody Vegetation } \\
\text { Less than } 5 \text { Metres } \\
\text { HAT }\end{array}$ & \multirow[t]{3}{*}{$\begin{array}{l}\text { Mooney and Petter } \\
\text { (unpublished } \\
\text { manuscript) }\end{array}$} & & \\
\hline $\begin{array}{l}\text { Woody Vegetation } \\
\text { on Slopes }\end{array}$ & & & \\
\hline $\begin{array}{l}\text { Woody Vegetation } \\
\text { on Streams }\end{array}$ & & & \\
\hline Wetlands & DERM (2008) & $\begin{array}{l}\text { Wetland vegetation reduces the flow of floods and } \\
\text { the wetlands store additional water flows (United } \\
\text { States Environmental Protection Agency 2006). }\end{array}$ & \\
\hline Islands & DERM (2008) & $\begin{array}{l}\text { Islands can buffer mainlands from disturbances } \\
\text { such as tsunamis (Hanson et al. 2002). }\end{array}$ & \\
\hline
\end{tabular}




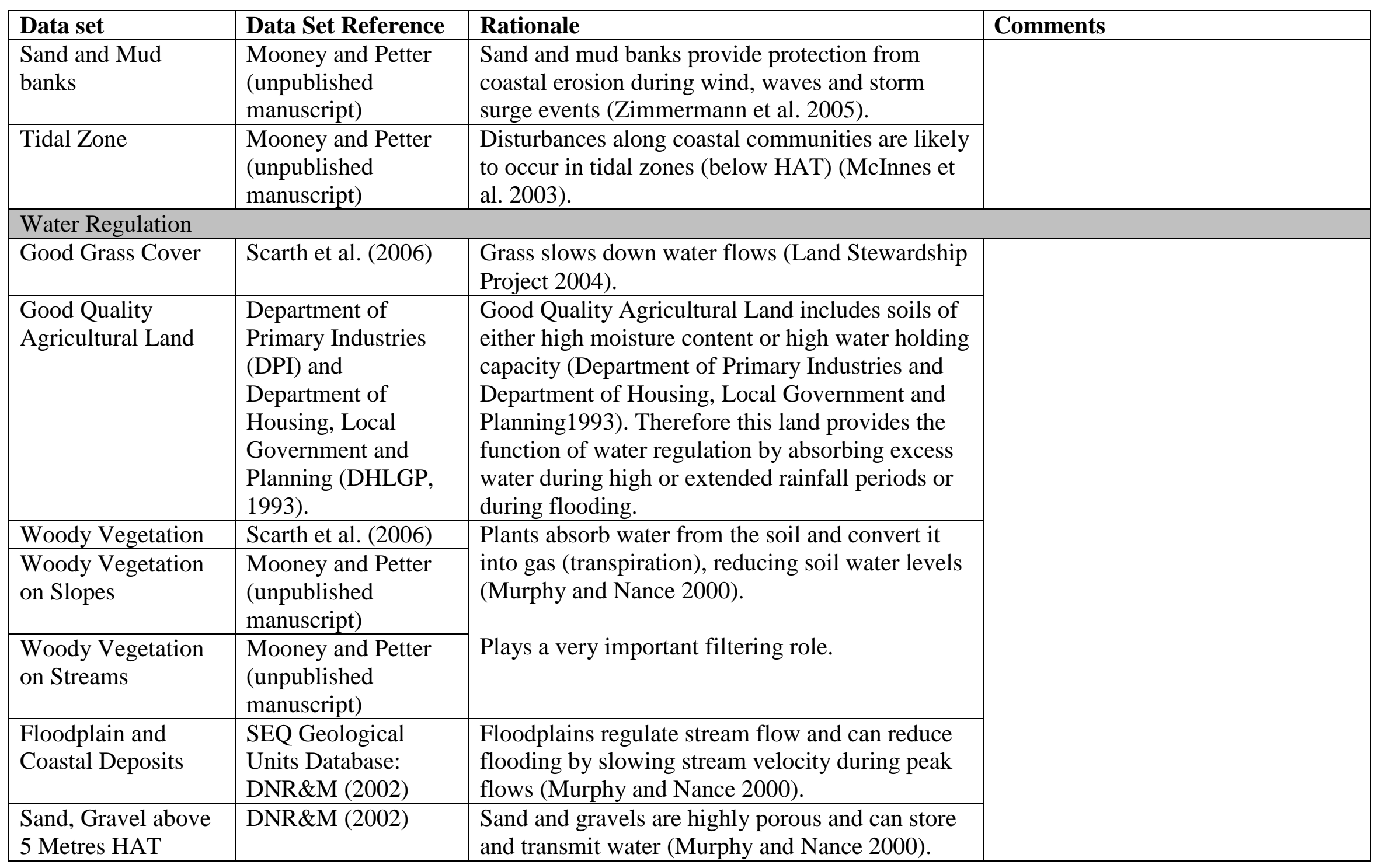




\begin{tabular}{|c|c|c|c|}
\hline Data set & Data Set Reference & Rationale & Comments \\
\hline Wetlands & $\begin{array}{l}\text { Environmental } \\
\text { Protection Agency } \\
\text { (EPA 2008) }\end{array}$ & $\begin{array}{l}\text { Wetland vegetation reduces the flow of floods and } \\
\text { the wetland stores additional water flows (United } \\
\text { States Environmental Protection Agency 2006). }\end{array}$ & \\
\hline Good Grass Cover & Scarth et al. (2006) & $\begin{array}{l}\text { Groundcover reduces soil erosion (Prosser et al. } \\
2000 \text { ) }\end{array}$ & \multirow{4}{*}{$\begin{array}{l}\text { This function refers to the rate at } \\
\text { which soil moves around the } \\
\text { landscape as opposed to its rate of } \\
\text { natural formation. }\end{array}$} \\
\hline Woody Vegetation & Scarth et al. (2006) & $\begin{array}{l}\text { Forested areas have soils with high stability, soil } \\
\text { health, and infiltration rates, and low erodibility } \\
\text { (Young 1989). }\end{array}$ & \\
\hline $\begin{array}{l}\text { Vegetation on } \\
\text { Slopes }\end{array}$ & $\begin{array}{l}\text { Mooney and Petter } \\
\text { (unpublished } \\
\text { manuscript) }\end{array}$ & $\begin{array}{l}\text { Vegetation on slopes reduces erosion rates } \\
\text { (Prosser et al. 2000) }\end{array}$ & \\
\hline $\begin{array}{l}\text { Vegetation on } \\
\text { Streams }\end{array}$ & $\begin{array}{l}\text { Mooney and Petter } \\
\text { (unpublished } \\
\text { manuscript) }\end{array}$ & $\begin{array}{l}\text { Streams with vegetation on surrounding banks are } \\
\text { much less prone to erosion than bare stream banks } \\
\text { (Beeson and Doyle 1995). }\end{array}$ & \\
\hline $\begin{array}{l}\text { Mangroves, } \\
\text { Samphire and Salt } \\
\text { Marshes }\end{array}$ & $\begin{array}{l}\text { EPA (Young and } \\
\text { Dillewaard 1999). }\end{array}$ & $\begin{array}{l}\text { Mangroves are sites of high nutrient cycling } \\
\text { (Tomlinson 1994). Salt marshes are nutrient } \\
\text { cycling sites (Broome et al. 1988). }\end{array}$ & \multirow{5}{*}{$\begin{array}{l}\text { Southern Moreton Bay is highlighted } \\
\text { as an important area for nutrient } \\
\text { regulation due to the location of } \\
\text { these ecosystems and related } \\
\text { biophysical factors. } \\
\text { The Wader Habitat layer could also } \\
\text { be included in the nutrient regulation } \\
\text { function as supported by de Groot et } \\
\text { al. (2002: 399)“migration (of birds, } \\
\text { fish and mammals) plays an } \\
\text { important role in the distribution of } \\
\text { nutrients between ecosystems". }\end{array}$} \\
\hline Fish Habitat Areas & $\begin{array}{l}\text { Queensland } \\
\text { Fisheries Service- } \\
\text { Marine Habitat 2000) }\end{array}$ & $\begin{array}{l}\text { Areas of fish habitat are nutrient cycling sites } \\
\text { (Broome et al. 1988). }\end{array}$ & \\
\hline Good Grass Cover & Scarth et al. (2006) & \multirow{3}{*}{$\begin{array}{l}\text { Grasses and plants contribute to nutrient cycling } \\
\text { in soils (Murphy and Nance 2000). }\end{array}$} & \\
\hline $\begin{array}{l}\text { Good Quality } \\
\text { Agricultural Land }\end{array}$ & $\begin{array}{l}\text { DPI and DHLGP } \\
\text { (1993). }\end{array}$ & & \\
\hline Woody Vegetation & Scarth et al. (2006) & & \\
\hline
\end{tabular}




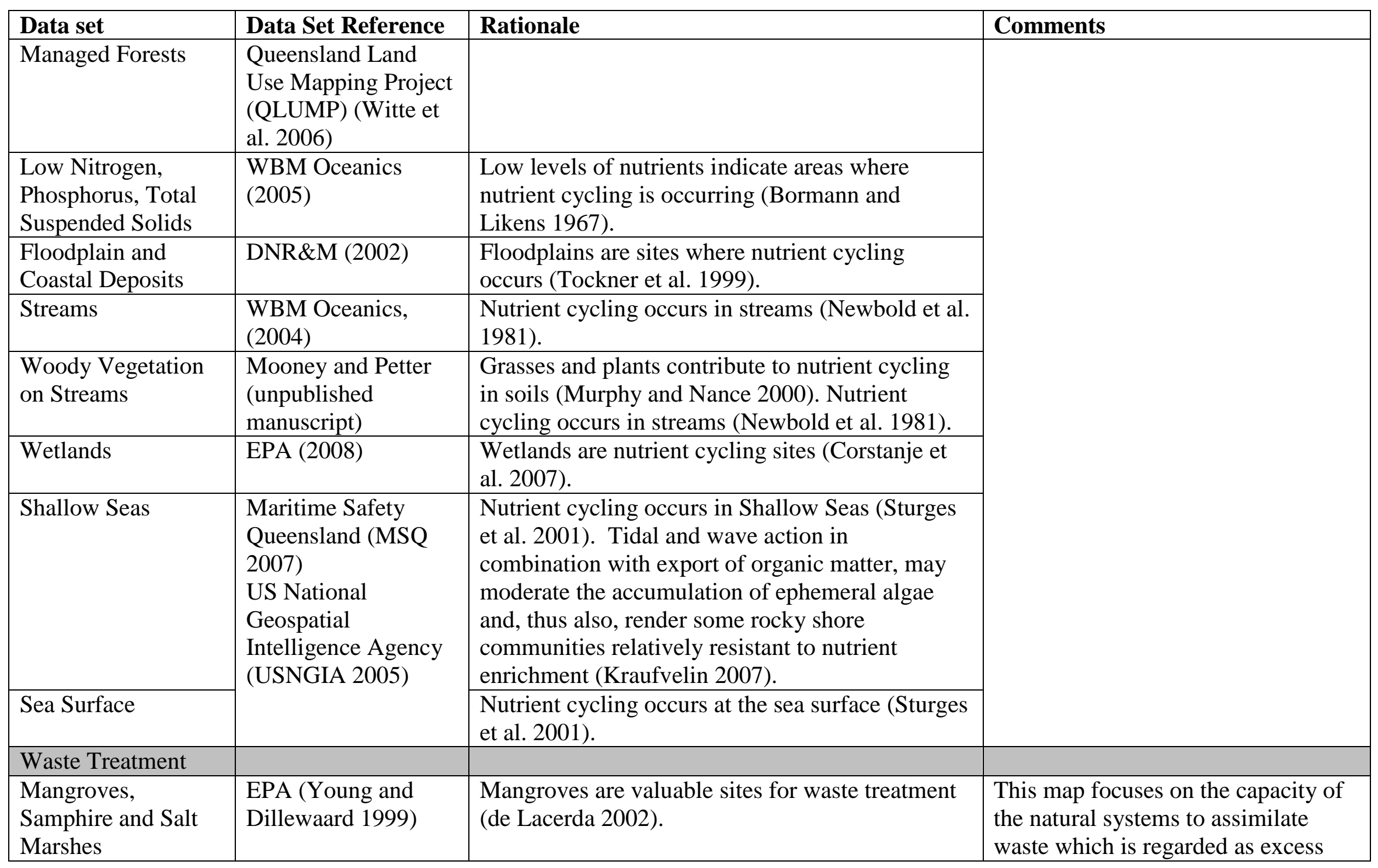




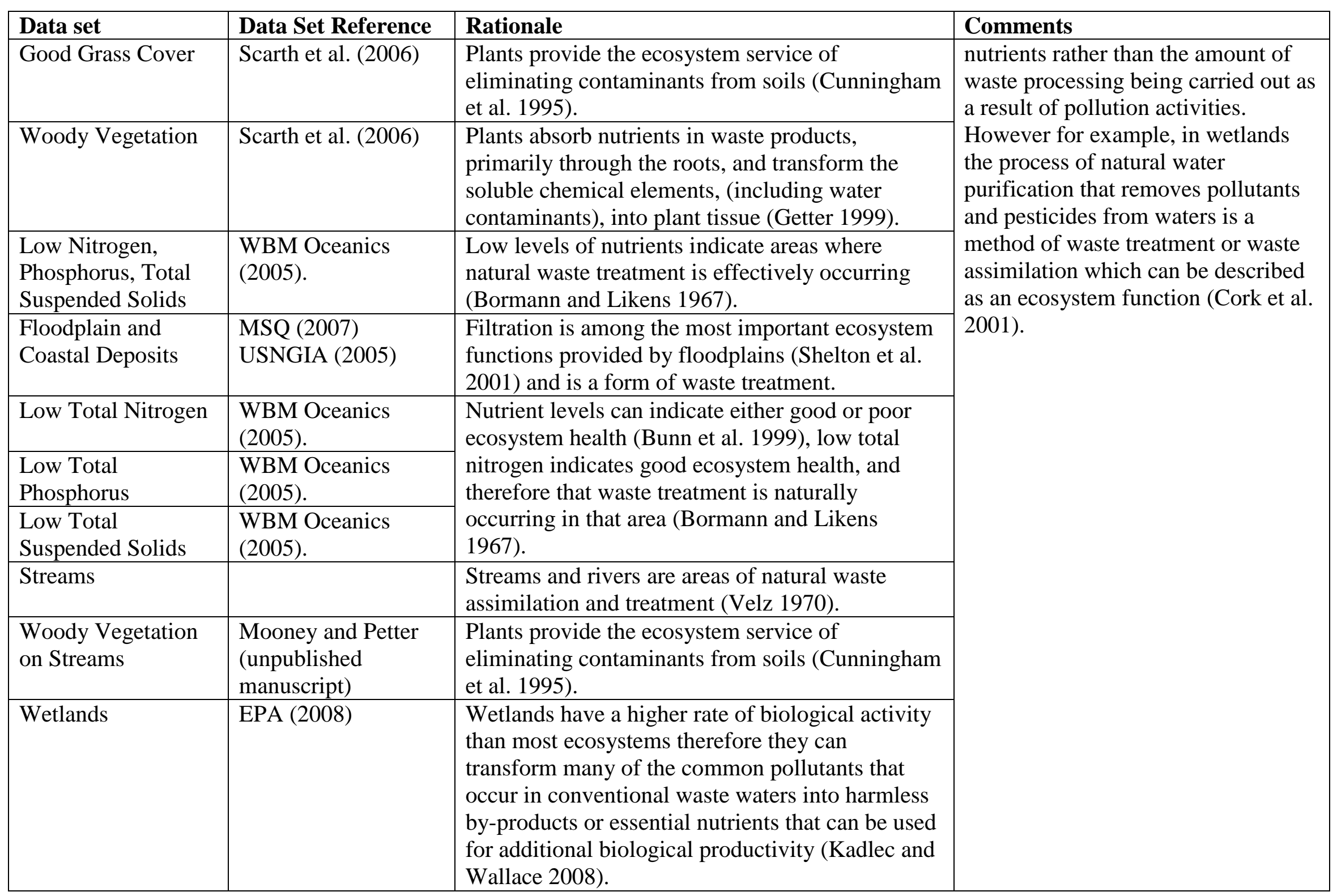




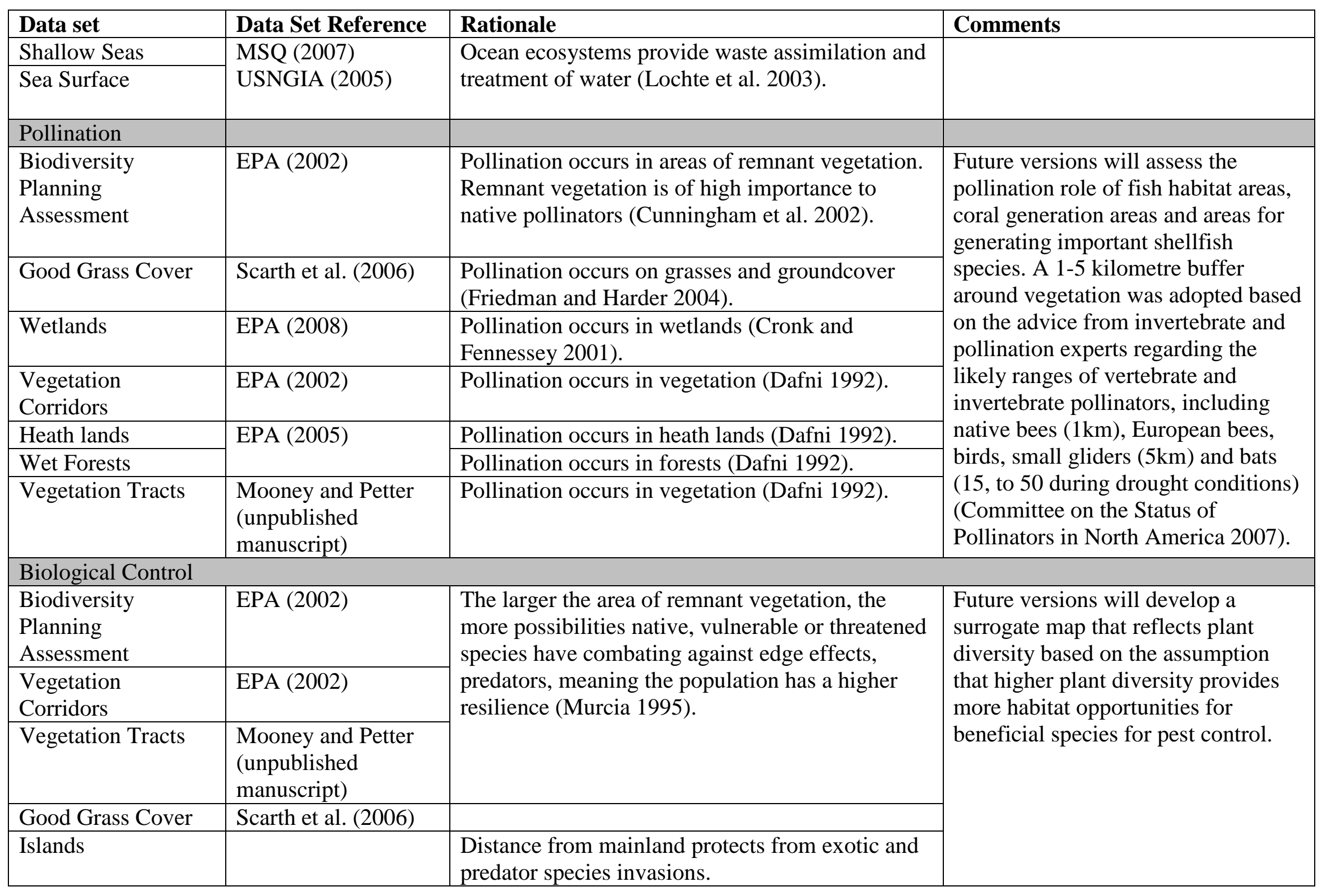




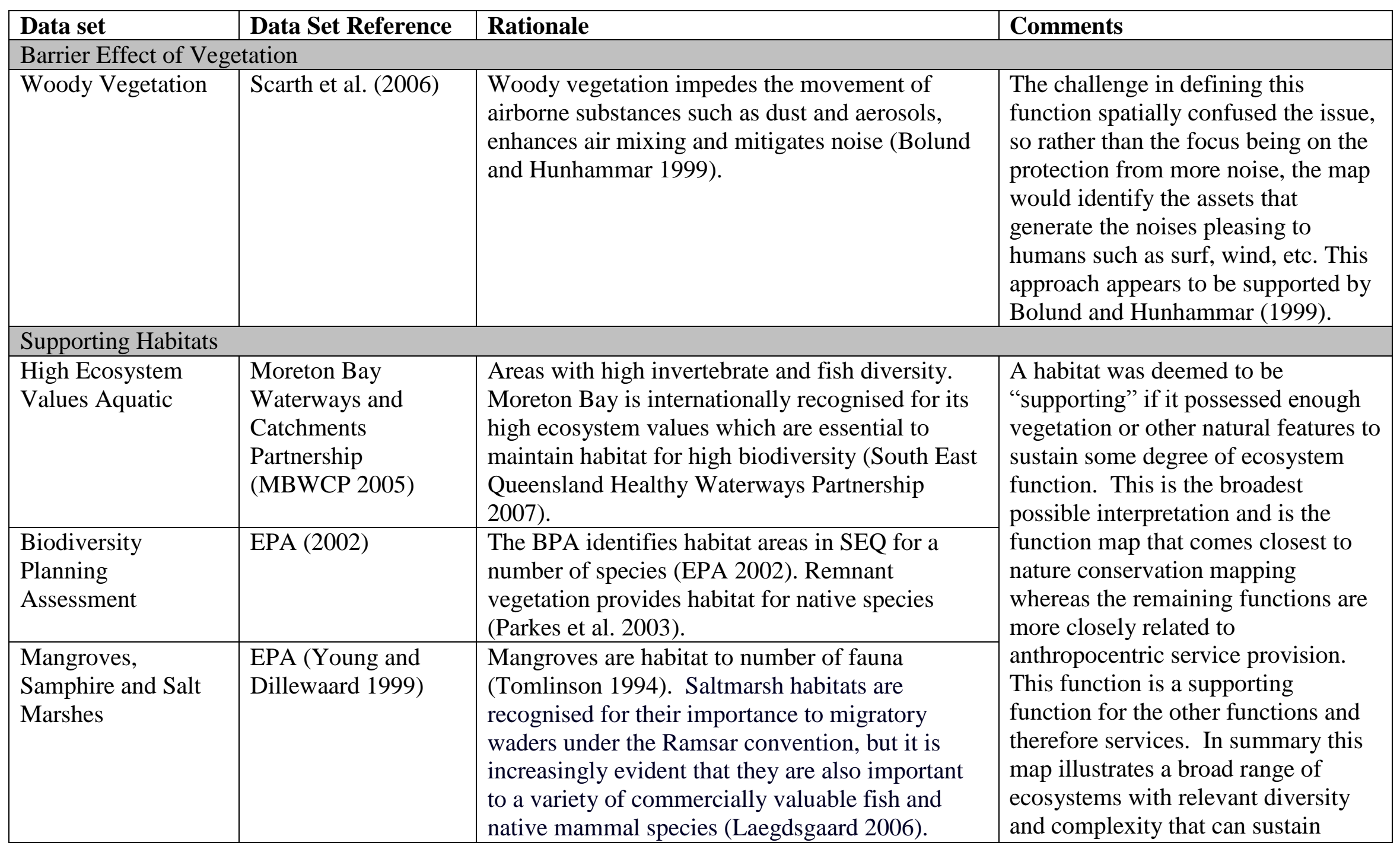




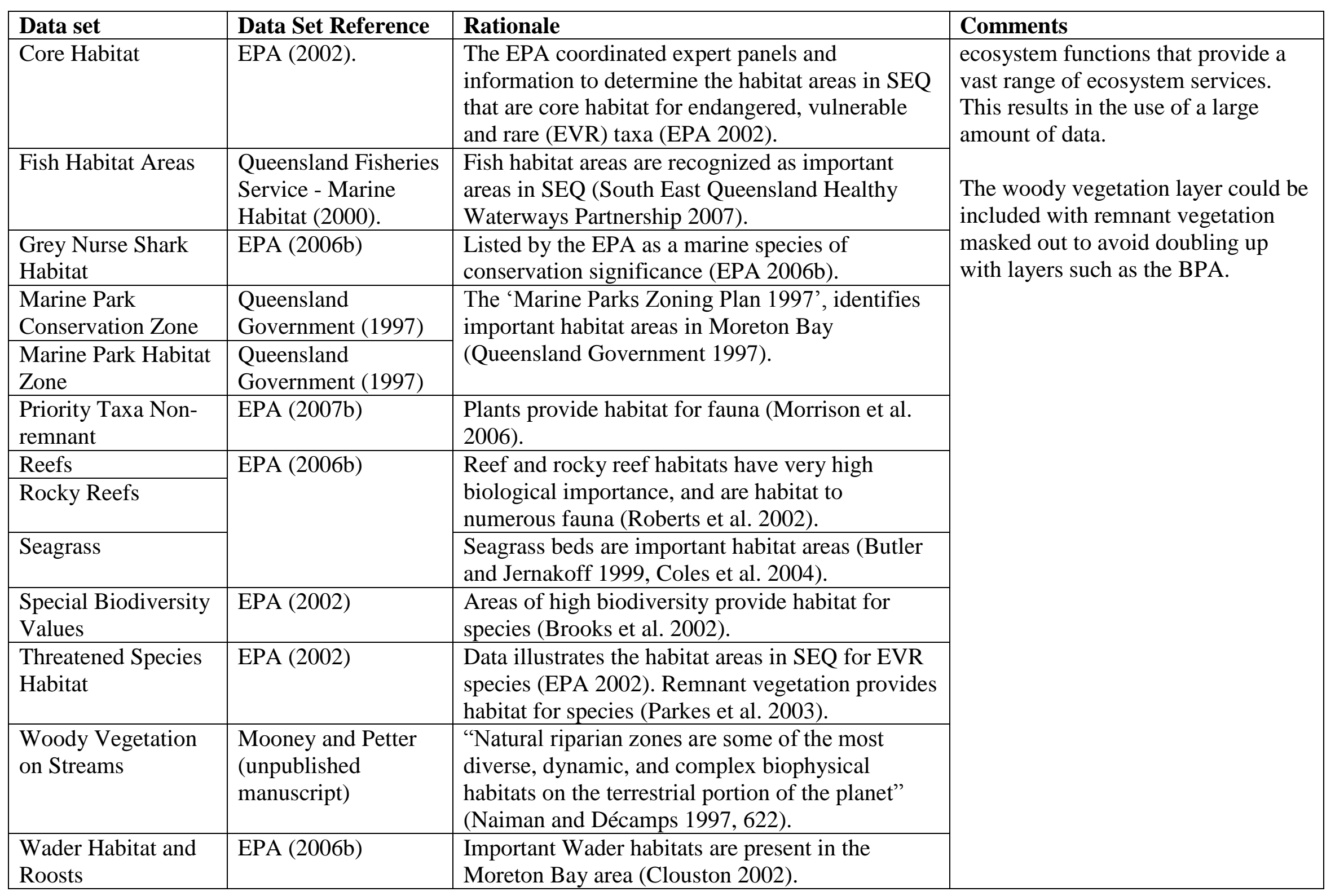




\begin{tabular}{|c|c|c|c|}
\hline Data set & Data Set Reference & Rationale & Comments \\
\hline Wetlands & EPA (2008) & $\begin{array}{l}\text { Wetlands provide a wide variety of habitats for } \\
\text { fish, invertebrates, amphibians, reptiles, } \\
\text { mammals, and birds (Cronk and Fennessey 2001). }\end{array}$ & \\
\hline Vegetation Tracts & $\begin{array}{l}\text { Mooney and Petter } \\
\text { (unpublished } \\
\text { manuscript) }\end{array}$ & $\begin{array}{l}\text { Vegetation corridors/tracts provide important } \\
\text { habitat for native fauna species (Bennett 1990). } \\
\text { Plants provide habitat (Morrison et al. 2006). }\end{array}$ & \\
\hline $\begin{array}{l}\text { Sand and Mud } \\
\text { banks }\end{array}$ & \multirow{2}{*}{$\begin{array}{l}\text { MSQ (2007) } \\
\text { USNGIA (2005) }\end{array}$} & $\begin{array}{l}\text { Sand and mud banks are habitat areas (Lloyd and } \\
\text { Cook 2002). }\end{array}$ & \\
\hline Sea Surface & & $\begin{array}{l}\text { The Moreton Bay area is habitat for many marine } \\
\text { species (Queensland Government 1997). }\end{array}$ & \\
\hline $\begin{array}{l}\text { Mangroves, } \\
\text { Samphire and Salt } \\
\text { Marshes }\end{array}$ & $\begin{array}{l}\text { EPA (Young and } \\
\text { Dillewaard 1999: } \\
\text { 12/6). }\end{array}$ & $\begin{array}{l}\text { Mangroves and salt marshes are places where } \\
\text { sedimentation occurs and soils are deposited } \\
\text { (Rogers et al. 2005). }\end{array}$ & \multirow{5}{*}{$\begin{array}{l}\text { Jenny (1994, 148) states "from the } \\
\text { viewpoint of soil formation, the most } \\
\text { important classes of vegetation are } \\
\text { forests, grasses, and desert shrubs. } \\
\text { Jenny (1994, 141) quotes Joffe } \\
\text { (1949), stating "without plants, no } \\
\text { soil can form." However, it is highly } \\
\text { debated among soil scientists as to } \\
\text { whether organisms and vegetation } \\
\text { actually contribute to the formation } \\
\text { of soil (Jenny 1994, 141). "In all } \\
\text { studies of soil-climate relationships, } \\
\text { vegetation is treated as a dependent } \\
\text { variable rather than as a soil-forming } \\
\text { factor" (Jenny 1994, 141). }\end{array}$} \\
\hline Good Grass Cover & DNR\&M (2005). & Site where soil formation occurs (Jenny 1994). & \\
\hline $\begin{array}{l}\text { Good Quality } \\
\text { Agricultural Land }\end{array}$ & $\begin{array}{l}\text { DPI and DHLGP } \\
\text { (1993). }\end{array}$ & $\begin{array}{l}\text { Contributes organic matter (Schnitzer and Khan } \\
\text { 1978) and soils are deposited here (Phillips et al. } \\
\text { 1999). }\end{array}$ & \\
\hline $\begin{array}{l}\text { Floodplain and } \\
\text { Coastal Deposits }\end{array}$ & $\begin{array}{l}\text { MSQ (2007) } \\
\text { USNGIA (2005) }\end{array}$ & $\begin{array}{l}\text { Weathered soils are transported and deposited } \\
\text { here (Gerrard 1992). }\end{array}$ & \\
\hline $\begin{array}{l}\text { Woody Vegetation } \\
\text { on Slopes }\end{array}$ & $\begin{array}{l}\text { Mooney and Petter } \\
\text { (unpublished } \\
\text { manuscript) }\end{array}$ & $\begin{array}{l}\text { Contributes organic matter which is important in } \\
\text { soil formation (Schnitzer and Khan 1978). Site } \\
\text { where soil formation occurs (Jenny 1994). }\end{array}$ & \\
\hline
\end{tabular}




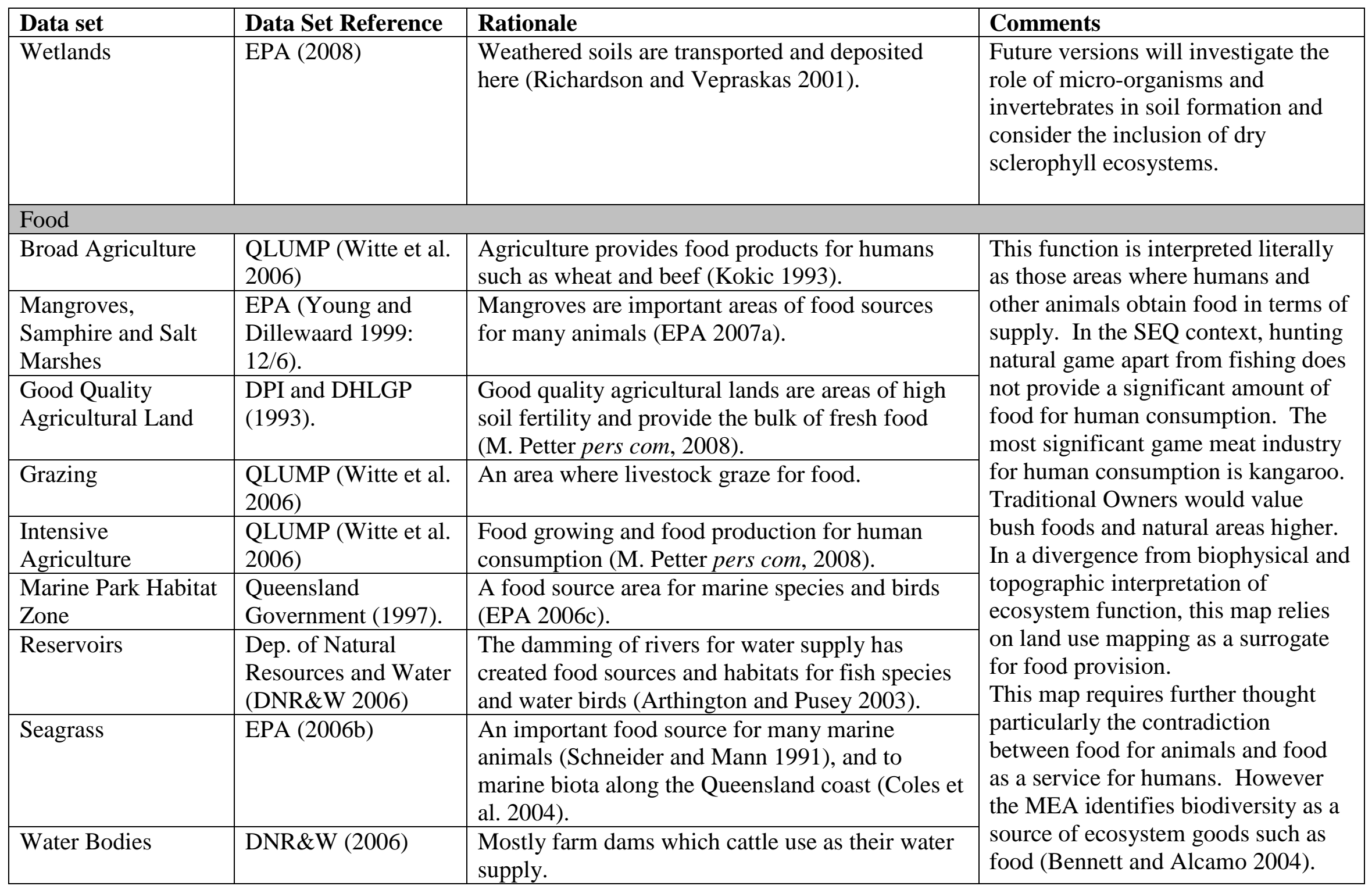




\begin{tabular}{|c|c|c|c|}
\hline Data set & Data Set Reference & Rationale & Comments \\
\hline Shallow seas & \multirow[t]{2}{*}{$\begin{array}{l}\text { MSQ (2007) } \\
\text { USNGIA (2005) }\end{array}$} & $\begin{array}{l}\text { Photosynthesis provides food for autotrophic } \\
\text { organisms (Garrison 2007). }\end{array}$ & \\
\hline Tidal Zone & & $\begin{array}{l}\text { A variety of marine species feed in tidal zones } \\
\text { (Pihl 1985). }\end{array}$ & \\
\hline \multicolumn{4}{|l|}{ Raw Materials } \\
\hline Woody Vegetation & Scarth et al. (2006) & $\begin{array}{l}\text { Woody vegetation (trees and shrubs) planted for } \\
\text { wood production (Kavanagh et al. 2005). }\end{array}$ & \multirow{3}{*}{$\begin{array}{l}\text { Hunting for skins or furs is not a } \\
\text { significant part of mainstream } \\
\text { culture in SEQ which leaves areas of } \\
\text { timber as the principle raw material } \\
\text { to map. } \\
\text { A layer illustrating areas of private } \\
\text { farm forestry would enhance this } \\
\text { map. }\end{array}$} \\
\hline Plantations & $\begin{array}{l}\text { QLUMP (Witte et al. } \\
\text { 2006) }\end{array}$ & $\begin{array}{l}\text { Australia's plantations are an important source of } \\
\text { hard and softwood supplies (Department of } \\
\text { Agriculture, Fisheries and Forestry 2005). }\end{array}$ & \\
\hline $\begin{array}{l}\text { Vegetation } \\
\text { Corridors }\end{array}$ & EPA (2002) & $\begin{array}{l}\text { Woody vegetation (trees and shrubs) planted for } \\
\text { wood production (Kavanagh et al. 2005). }\end{array}$ & \\
\hline FLAG lowup & (Roberts et al. 1997) & $\begin{array}{l}\text { Areas where groundwaters are likely to } \\
\text { accumulate (Roberts et al. 1997). }\end{array}$ & \multirow{4}{*}{$\begin{array}{l}\text { The layers used to produce this map } \\
\text { are considered indicators of a } \\
\text { catchment in good health and } \\
\text { functioning well to supply water. } \\
\text { These areas are largely unmodified } \\
\text { by human practices and can therefore } \\
\text { be expected to be playing a very } \\
\text { important water supply role. } \\
\text { The MEA provides evidence that } \\
\text { terrestrial plants provide water } \\
\text { quality through the biological } \\
\text { processes they undergo (eg. during } \\
\text { evapotranspiration) (Bennett and } \\
\text { Alcamo 2004). }\end{array}$} \\
\hline $\begin{array}{l}\text { Good Quality } \\
\text { Agricultural Land }\end{array}$ & $\begin{array}{l}\text { DPI and DHLGP } \\
(1993) .\end{array}$ & $\begin{array}{l}\text { Good quality soils have high water content and } \\
\text { retention capacity (Arshad and Martin 2002) or } \\
\text { may occur above groundwater reserves. }\end{array}$ & \\
\hline $\begin{array}{l}\text { High Density of } \\
\text { Headwater Streams }\end{array}$ & $\begin{array}{l}\text { Mooney and Petter } \\
\text { (unpublished } \\
\text { manuscript) }\end{array}$ & & \\
\hline $\begin{array}{l}\text { Low Nitrogen, } \\
\text { Phosphorus, Total } \\
\text { Suspended Solids }\end{array}$ & $\begin{array}{l}\text { WBM Oceanics } \\
(2005) \text {. }\end{array}$ & $\begin{array}{l}\text { Cleaner water is more likely to contribute to water } \\
\text { supply (M. Petter pers com, 2008). }\end{array}$ & \\
\hline
\end{tabular}




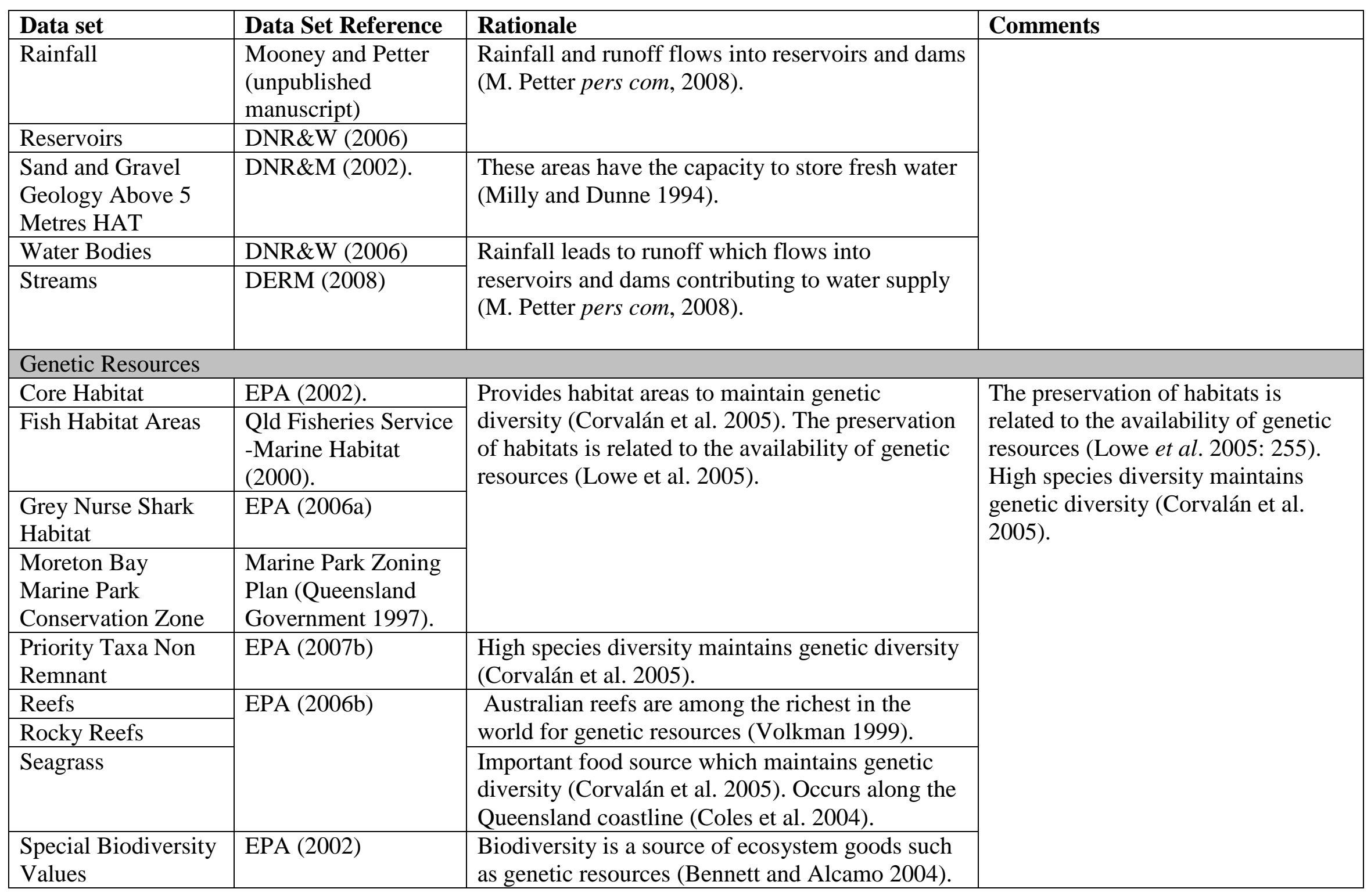




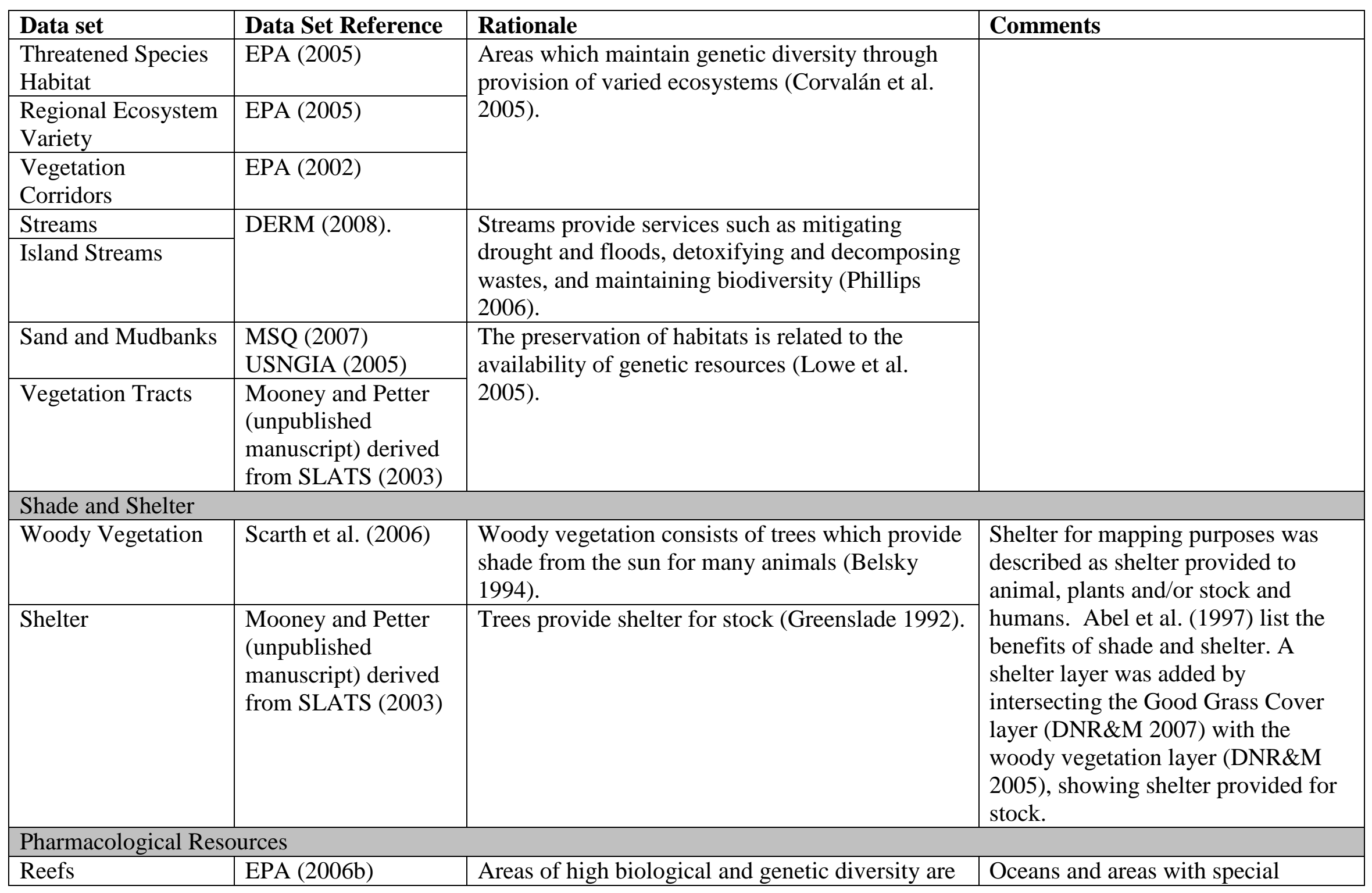




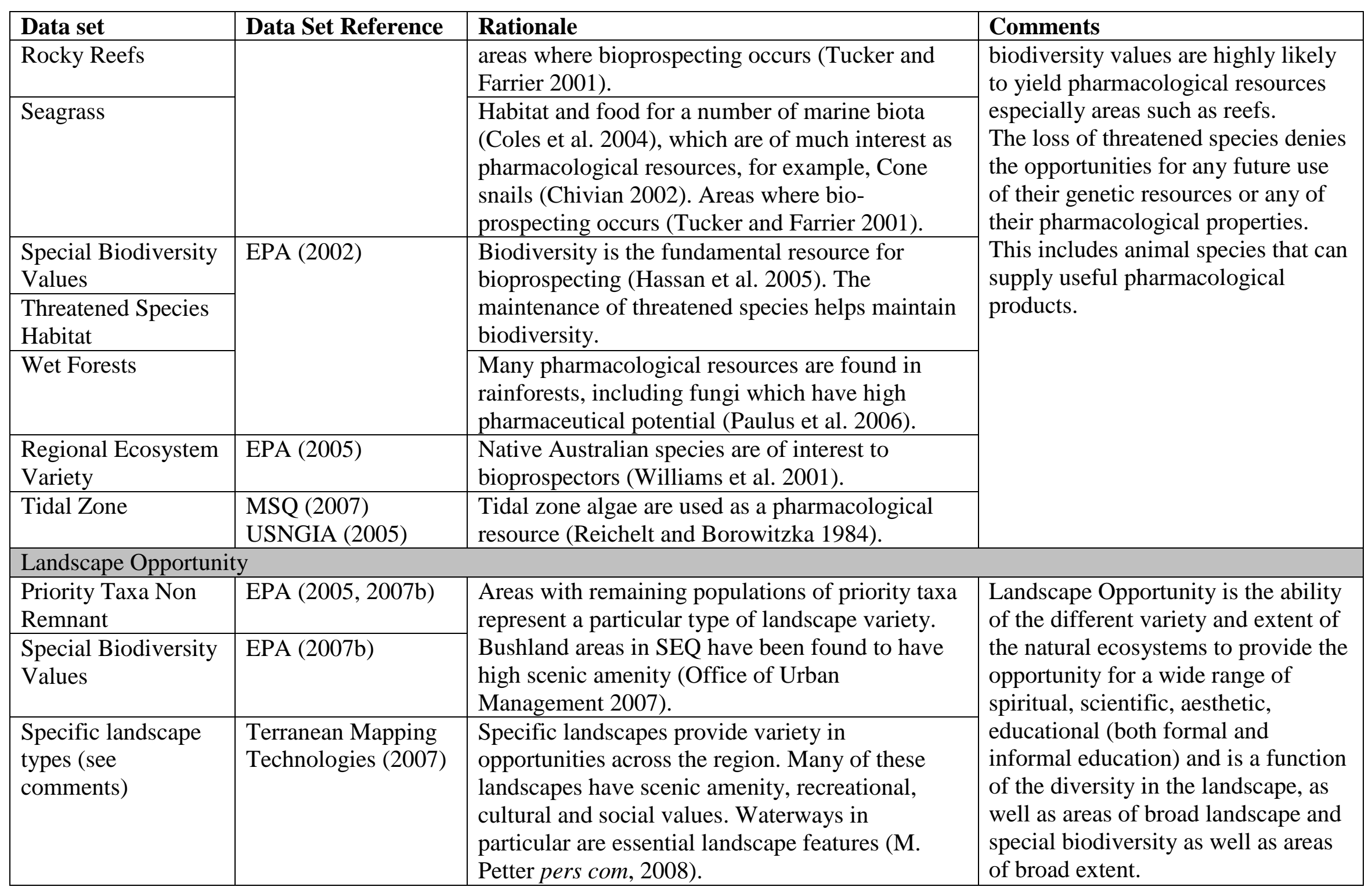




\begin{tabular}{|c|c|c|c|}
\hline Data set & Data Set Reference & Rationale & Comments \\
\hline $\begin{array}{l}\text { Vegetation } \\
\text { Corridors }\end{array}$ & EPA (2002) & $\begin{array}{l}\text { Corridors provide essential connections between } \\
\text { landscapes and the extensive edges offer a high } \\
\text { degree of landscape diversity (M. Petter pers com, } \\
\text { 2008). }\end{array}$ & \multirow{4}{*}{$\begin{array}{l}\text { Specific landscape types included: } \\
\text { Mangroves, Samphire and Salt } \\
\text { Marshes } \\
\text { Reefs/Rocky Reefs } \\
\text { Reservoirs } \\
\text { Seagrass } \\
\text { Water bodies } \\
\text { Streams } \\
\text { Wetlands } \\
\text { Heathlands } \\
\text { Islands } \\
\text { Island streams } \\
\text { Midlands } \\
\text { Mountains } \\
\text { Wet forests } \\
\text { Sand and Mudbanks } \\
\text { Sea Surface } \\
\text { Tidal Zone }\end{array}$} \\
\hline Good Streams & DERM (2008) & $\begin{array}{l}\text { Healthy streams provide recreational and cultural } \\
\text { amenity, eg. Water sports, Bird-watching (Bennett } \\
\text { and Alcamo 2004) and are identified in the SEQ } \\
\text { Regional Plan as having "significant scenic } \\
\text { amenity" (Office of Urban Management 2007). } \\
\text { Watercourses in SEQ provide scenic amenity } \\
\text { (Preston 2001, Office of Urban Management } \\
\text { 2007). }\end{array}$ & \\
\hline $\begin{array}{l}\text { Landscape variety: } \\
\text { - Geodiversity } \\
\text { - } \quad \text { RE Variety }\end{array}$ & $\begin{array}{l}\text { DNR\&M (2002) } \\
\text { EPA (2005) }\end{array}$ & $\begin{array}{l}\text { The diversity of geological features supports } \\
\text { diversity of regional ecosystems (M. Petter pers } \\
\text { com, 2008). }\end{array}$ & \\
\hline Scenic Preference & $\begin{array}{l}\text { Council of Mayors } \\
\text { SEQ (South East } \\
\text { Queensland Regional } \\
\text { Organisation of } \\
\text { Councils 2005) } \\
\end{array}$ & $\begin{array}{l}\text { Areas of high scenic preference (or beauty) } \\
\text { provide unique opportunities and inspiration } \\
\text { (South East Queensland Regional Organisation of } \\
\text { Councils 2005). }\end{array}$ & \\
\hline
\end{tabular}


Appendix 3. Figure A3.1- Map of Ecosystem Function 03 (Disturbance Regulation)

Please click here to download file 'appendix3.pdf'. 
Ecology and Society 18(1): 31 http://www.ecologyandsociety.org/vol18/iss1/art31/

\section{APPENDIX 4}

\section{Figure A4.1. Output Map of Total Ecosystem Function - Simple Overlap}

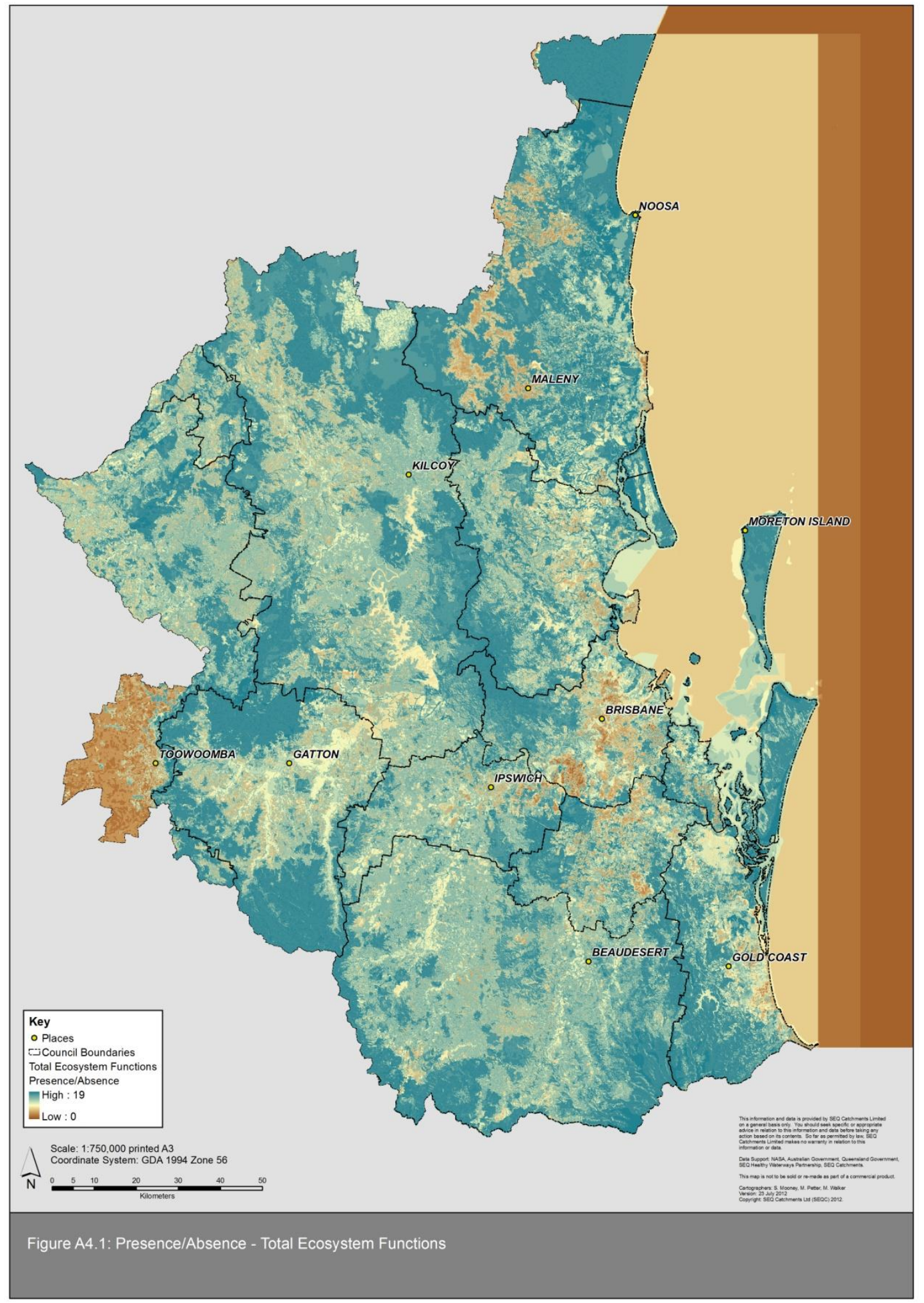




\section{APPENDIX 5}

Figure A5.1. Output Map of Total Ecosystem Function - Quantile Overlap

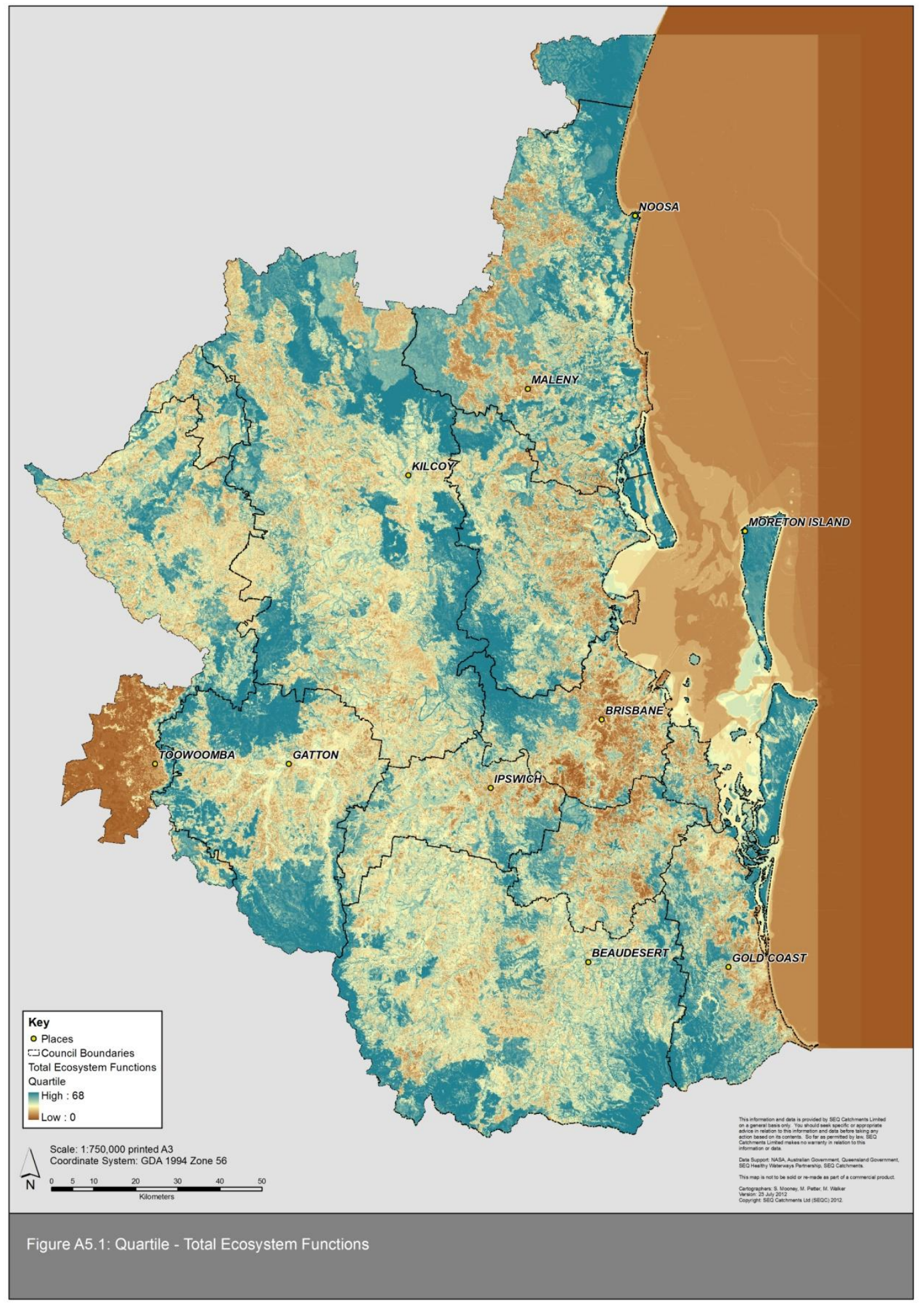


